\title{
CONSTITUCIONES Y CRECIMIENTO ECONÓMICO EN LA COLOMBIA DEL SIGLO XIX *
}

SALOMÓN KALMANOVITZ

Universidad de Bogotá Jorge Tadeo Lozano ${ }^{\mathrm{a}}$

\section{RESUMEN}

En este ensayo analizo el impacto de las numerosas constituciones que se redactaron en la Colombia del siglo XIX sobre su desarrollo económico. Se escogen algunas constituciones prototípicas como piezas importantes de la estructura legal que se va conformando en el país. Se trata de demostrar que la inestabilidad constitucional y legal fue más importante que el propio legado hispánico en explicar el retraso económico de Colombia. Mientras que los monopolios comerciales, políticos y religiosos fueron heredados y estuvieron a la base de la ideología conservadora, muchos de ellos lograron ser desmantelados por los reformistas liberales. La pérdida del orden político que España supo mantener por tres siglos fue seguida por la búsqueda tortuosa de un nuevo ordenamiento político, de lo cual fueron responsables las elites criollas. Los excesos de concentración o difusión de poderes mar-

* Received 01/11/2007. Accepted 05/27/2008. Agradezco el financiamiento provisto por el Banco de la República para adelantar esta investigación. Agradezco también la colaboración de Edwin López Rivera por su asistencia y por sus comentarios detallados. Recibí críticas valiosas de William Summerhill en el seminario Historia económica del siglo XIX organizado por el Banco de la República en Bogotá, 15 de agosto de 2007. También recibí comentarios valiosos en el Seminario de Historia del Pensamiento Colombiano de la Universidad Nacional, dirigido por Rubén Sierra y Lisímaco Parra. Jaime Urueña me proveyó luces sobre las cartas de Cartagena y de Cundinamarca. Por último, comentarios de los editores y de un evaluador anónimo de RHE contribuyeron a que este texto adquiriera claridad y precisión.

a Facultad de Ciencias Económico Administrativas. Apartado Aéreo 34185, Bogotá D. C., Colombia.kalmanovitz@cable.net.co. 
caron los movimientos pendulares entre centralismo y federalismo, que fueron de la esencia del desorden político del siglo XIX, freno importante a su vez del desarrollo económico del país.

Palabras clave: Colombia, historia constitucional, crecimiento económico

\begin{abstract}
In this essay I analyze the impact of the many constitutions Colombia drafted during the nineteenth century on its economic development. Some prototypical constitutions are chosen as they became building blocks of the legal structure of the country. I try to show that constitutional and legal instability played a more important role in the lack of development than the Spanish legacy. While commercial, political and religious monopolies were inherited and constituted the ideological base of the conservatives, many of them were dismantled by the liberal reforms. The loss of the political order which the Spanish had maintained for three centuries was followed by the painful search for a new political code, for which the Creole elites were responsible. The excesses of concentration or diffusion of power produced the pendulum movements between centralism and federalism which were essential causes of the political disorder during the nineteenth century, which held back the country's economic performance.
\end{abstract}

Key words: Colombia, constitutional history, economic growth Jel Classification: N16, N26, O43, O46

\title{
1. INTRODUCCIÓN
}

El papel que juegan las instituciones en el desarrollo económico ha sido destacado en la historiografía contemporánea; sus aplicaciones a distintos escenarios han permitido apreciar su riqueza de resultados ${ }^{1}$. Lo esencial para nosotros de este enfoque es el análisis de las instituciones políticas y, en particular, del legado absolutista en el origen del ordenamiento constitucional colombiano y el impacto que tuvo sobre su desarrollo económico de largo plazo. Si el surgimiento de Occidente se debió a la creación de un gobierno limitado por el parlamento y por un sistema de justicia indepen-

1 North (1993); Engerman, Sokoloff (1999, 2003); Acemoglu, Johnson, Robinson (2001 y 2005); Summerhill, North, Weinsgast (2005). 
diente que facilitaron el desarrollo económico [North, Weinsgat (1989), 804 y 805], en el caso de España y de sus colonias la revolución democrática fue frustrada y ello debió frenar su crecimiento económico, o mejor, éste careció de las condiciones institucionales necesarias y suficientes para garantizar su profundización en el largo plazo. Sin embargo, España estableció un orden político estable por tres siglos, algo que los criollos no pudieron replicar en su vida independiente y que constituyó el mayor freno a su crecimiento durante el siglo XIX, de tal modo que queda en el aire hasta donde el legado hispánico explica la falta de desarrollo en sus excolonias.

Otra vertiente teórica cuestiona que las buenas instituciones sean la fuente del crecimiento económico e invierten la causalidad: es el crecimiento, a veces impulsado por regímenes dictatoriales que imponen un orden político, combinado con buenas políticas económicas, como incrementos de capital humano, los que terminan mejorando la calidad de las instituciones [Glaeser et al. (2004)]. Aunque no profundizaremos en el debate con nuestros datos y análisis constitucional, aceptaremos que la prosperidad, no importa quién la impulse, puede generar estabilidad política, inversiones en infraestructuras, aumentos de la cobertura de la educación y eventualmente mejores instituciones. Sin embargo, el legado hispánico y absolutista en la historia de los países latinoamericanos dificultó la construcción de regímenes políticos democráticos y a veces frenó también el progreso económico. La inestabilidad se apropió de los países latinoamericanos que poco prosperaron en el siglo XIX, pero estalló también en los que se habían enriquecido con la primera globalización, cuando se deterioraron sus condiciones económicas en el siglo Xx.

Para el caso colombiano, son escasas las contribuciones en este campo, aunque hay estudios político-históricos y sociológicos que describen las instituciones, pero sin especificar su impacto sobre la economía. El objetivo de este ensayo es entonces analizar algunas instituciones formales, focalizando en las constituciones legadas por el Imperio español en el Nuevo Reyno de Granada y su posterior cambio y adaptación a las condiciones locales de la Gran Colombia, la Confederación Granadina y finalmente a la República de Colombia; se examinarán, en especial, sus efectos económicos.

El punto de partida será el de entender el papel que jugaron las constituciones en la organización política y económica del país en formación, desde la tradición constitucional española pensada por los filósofos Francisco de Vittoria y Francisco Suárez, basada en el derecho natural o de gentes $^{2}$. El análisis de algunas constituciones prototípicas se hará para mostrar elementos que parecen importantes en la estructura legal que se va

2 «El Estado, como un todo, es superior al rey, desde que el Estado que otorgó su poder lo hizo de acuerdo con las siguientes condiciones: que debería gobernar de acuerdo con la voluntad general y no tiránicamente; y que si no gobernase de esta manera, podrá ser depuesto de esa posición de poder», Francisco Suárez, Sobre la guerra, Disp. XIII. 
conformando en el país: la importancia del constitucionalismo tomista en el imaginario criollo que expresa su rechazo a la modernización borbónica; la ausencia de una revolución democrática tanto en España como en América, evidente en el fracaso de la constitución redactada por las cortes de Cádiz; el confesionalismo, presente en la mayor parte de las constituciones del siglo XIX, reflejo de la ausencia de competencia religiosa; la falta de una experiencia de gobierno proto-nacional, que explica la proliferación de constituciones locales y provinciales cuando se derrumbó el orden colonial; finalmente, los excesos de concentración o difusión de poderes que marcaron los movimientos pendulares entre centralismo y federalismo, que fueron de la esencia del desorden político del siglo XIX.

El ensayo consta de siete secciones, de la cual la primera es la introducción que acaba de leer. Un segundo tema será el de las constituciones posteriores a la independencia que analizará el legado español referido al derecho de rebelión o pactismo, la influencia de la constitución de Cádiz de 1812 y el surgimiento de un constitucionalismo localista después de la declaratorias de independencia en varias ciudades y regiones del todavía virreinato. Un tercer tema será el de las constituciones republicanas, la de Angostura y la de Cúcuta, ambas bajo la agenda del Libertador. La cuarta sección se dedica a las constituciones liberales y la constitución federal de 1863. Un quinto acápite dará cuenta del proceso de centralización política y la Constitución de 1886. En la sexta sección se investigará el comportamiento de largo plazo de la economía colombiana, muy influido por la inestabilidad política. La séptima sección alcanzará algunas conclusiones.

\section{CONSTITUCIONES POST-INDEPENDENTISTAS}

\subsection{Constituciones originarias}

En las colonias españolas el constitucionalismo tomista justificó la existencia de un pacto tácito entre los reinos asociados de ultramar y la Corona [Phelan (1980), 109], cimentado por algún grado de consenso entre los gobernados. Esta visión informaba que los pueblos y corporaciones que componen un reino han delegado su autonomía en el rey, quien debe responder con un buen gobierno. Si los pueblos eran acosados por la tiranía tenían el derecho de rebelarse contra el rey, aunque sólo en casos extremos [Burns (1991), 294 y 297]. Para el imperio de ultramar, el dominico Bartolomé de las Casas estableció que el rey infringía la ley fundamental y natural de los indígenas al entregarlos al arbitrio de los encomenderos y agregaba que "aquel que abusa de su autoridad no merece gobernar» [Burns (1991), 293], algo que el derecho indiano tomó en consideración y que justificó que la Corona recobrara el control sobre las encomiendas y las extinguiera progresivamente. 
Esta concepción sirvió de justificación a los movimientos comuneros de la Nueva Granada y del Perú cuando los borbones impusieron sin consulta nuevos impuestos y recrudecieron los estancos ${ }^{3}$. Antes de eso, la venta de cargos a criollos, el acceso a puestos en la Iglesia y la milicia por los criollos y cierta concordancia entre los intereses del rey y de sus pueblos dio lugar a un equilibrio político. La ley creada y defendida por la autoridad del rey podía ser cuestionada y los asuntos locales se orientaban bajo el lema, "se acata pero no se cumple». Tal equilibrio se resquebraja con la concepción absolutista y racional francesa del derecho introducida por los borbones en España y en América que exigió, por el contrario, la obediencia irrestricta de todos los súbditos a la ley emanada del poder real. Las reformas borbónicas fueron acompañadas por la restricción a la entrada de altos cargos de la administración, el ejército y la Iglesia por los locales, a la vez que se atacaban las prerrogativas de algunas órdenes, en particular la de los jesuitas [Brading (2003), 40].

Los criollos se sintieron desafectos con la nueva situación y estudiaron los textos de los Ilustrados, tanto las constituciones de los Estados Unidos como también las francesas, para darse una organización propia que difícilmente resemblaba la que se estaba dando en esos países. Las constituciones que se pensaron en la Nueva Granada también florecieron en todas las colonias ibéricas. «La idea de constitución que acompañó más habitualmente al momento de la quiebra de los espacios atlánticos ibéricos era mucho más global de lo que ha supuesto tradicionalmente la historiografía. En realidad lo era su cultura, el modo como se pensó y se reflexionó sobre la constitución» (Portillo).

Los criollos más conservadores enarbolaron el pasado feudal, católico y pactista como deseable, alejándose de las visiones constitucionales más modernas que surgieron con la revolución norteamericana y con la francesa. Tal tradición feudal fue utilizada frecuentemente para justificar que ellos, en efecto, contaban con una visión democrática de la política, aunque en verdad estaba lejos de pretender organizar una sociedad mercantil y dotar a sus miembros de derechos individuales inalienables, como fue surgiendo en el pensamiento constitucional moderno.

De acuerdo con Mauricio García-Villegas, la tradición latinoamericana de "pactismo» se originaría en ese derecho del pueblo a rebelarse si el rey incumplía sus deberes, donde la ley se desvanece frente al delito si éste se define como político o religioso (cuando, por ejemplo, el rey desobedece al sumo pontífice). En toda la historia constitucional posterior quedó vivo el concepto de delito político que implicaba un tratamiento flexible y benévolo para los insurgentes, lo cual reflejaba la ausencia de un sistema polí-

${ }^{3}$ Los borbones prohibieron la enseñanza del constitucionalismo tomista y expulsaron a los jesuitas de las colonias, quienes también enseñaban a Descartes, Leibnitz y Espinosa, junto con Suárez y Vittoria, a la juventud criolla [Elliot (2007), 329 y 333 ]. 
tico consensuado, la falta de un derecho que emanara del pueblo que tratara a todos por igual y alcanzara la legitimidad suficiente como para ser obedecido rigurosamente por todos. Esta inclinación fue continuada por el constitucionalismo liberal que entendió con simpatía los motivos altruistas de los rebeldes, motivos que en algunos casos justificaron transgresiones monstruosas del derecho. En todo caso, el pactismo inició una tradición de falta de rigor en la aplicación de la ley que tendió a debilitar el orden político.

La falta de una tradición de autogobierno por parte de los criollos, a quienes no se les permitió ejercer la administración económica y política del territorio, hizo difícil la construcción de escenarios nacionales de negociación. La Corona española delegó pocos poderes en manos de las instituciones locales como los cabildos y, al igual que en la metrópolis, desdeñó y desconoció las instituciones consultivas que prefiguraron los parlamentos, las cortes en el caso español [North, Summerhill, Weinsgat (2002), 36] ${ }^{4}$.

El monopolio del comercio internacional en manos de los consulados de Cádiz y Cartagena y las restricciones al comercio intra-colonial, frenaron la conformación de una burguesía criolla, que surgió débilmente sobre la base de la internación de las importaciones, con el contrabando que pudo representar 15 por cien del comercio legal [Meisel (2005)], como también en el comercio interior, en los poros de la minería que intercambiaba oro en polvo con las regiones productoras de alimentos y de artesanías. Aunque los borbones liberaron el comercio inter-colonial y debilitaron el poder de los consulados, los efectos no alcanzaron a consolidarse antes de que el imperio español, en efecto, colapsara en 1808 . No había por tanto tampoco una concepción de comercio libre y de sus ventajas, que diera lugar a un mercado común entre los virreinatos, como si lo hubo, por contraste, entre las trece colonias anglosajonas del norte de América. Por lo demás, a diferencia de sus contrapartes del norte, las colonias españolas se extendían por una inmensa geografía que hacían imposible la coordinación política y multiplicaban los costos de transporte, dificultando al día de hoy el comercio al interior del continente iberoamericano.

El derecho indiano se desprendió del derecho de Castilla y se desarrolló de manera flexible en los reinos de ultramar: los oidores y jueces tuvieron en cuenta en sus fallos los temas de "derecho» bajo el lema "a cada cual lo suyo", de equidad y de comunidad [Cutter (1999), 13]. Muchos de los caciques indígenas conservaron privilegios de mando y pudieron defender sus comunidades de las pretensiones de los criollos sobre sus tierras y labor. Esta flexibilidad también incidió en que las reglas de juego fueran varia-

4 En las 13 colonias anglosajonas, por el contrario, todas contaban con asambleas que asumían funciones tributarias y económicas que se asociaron en los congresos continentales para enfrentar a la metrópoli, una vez desatada la insurrección. El fomento del comercio fue creando unas fuertes capas financieras y empresariales nativas que fueron instrumentales en la independencia de los Estados Unidos. 
bles, imprecisas y ambiguas. La existencia de numerosos fueros que atendían negocios de indígenas, religiosos, mayorazgos, comerciantes, mineros, funcionarios de la corona, militares, de impuestos, en total unas 15 cortes especializadas, daban lugar a litigios incluso sobre cual corte debía decidir qué negocio, lo que se prestaba para aplazar o negar justicia. Cada una de ellas podía emitir fallos distintos sobre los mismos asuntos, rompiendo el principio de coherencia legal o sea que casos similares dan lugar a fallos similares.

Los fueros para comerciantes y mineros que se desarrollaron tardíamente redujeron los costos de litigación y, por tanto, de transacción de tan cruciales actividades económicas, siendo particularmente exitosas en el fomento de la producción de oro en la Nueva Granada. El problema es que «las cortes especiales tienen efectos negativos en la eficiencia con que se definen y aplican los derechos generales de propiedad..., pues las jurisdicciones sobrepuestas causaban gran confusión» [Coatsworth, Tortella (2007), 56 y 57]. Al negar la igualdad frente a la ley, el régimen sólo defiende algunos derechos de propiedad en detrimento de otros y limita, por tanto, la competencia económica ${ }^{5}$. Monopolios o escasa competencia conducen, a su vez, a la llanura de los mercados y a un desarrollo económico lento y tortuoso. Faltaba un sistema legal que facilitara el desarrollo de los negocios, como lo plantean Coatsworth y Tortella:

«España y sus colonias no desarrollaron ni las protecciones suministradas por principios legales uniformes ni la relativa transparencia y flexibilidad autorizada que se delegaba en jurados y los jueces locales en los sistemas de derecho común. Por el contrario, el sistema español funcionaba gracias a la flexibilidad no autorizada en la aplicación de leyes minuciosamente detalladas especificadas por parte de jueces y funcionarios cuyas acciones eran raras veces públicas y revisadas, aún por autoridades superiores» [Coatsworth, Tortella (2007), 59].

El sistema legal no le prestaba autonomía a los jueces y eran las autoridades reales o el consejo de Indias las que redactaban minuciosamente miles de ordenanzas y regulaciones que debían ser implementadas por funcionarios que ni siquiera las entendían y que los afectados podían reclamar ante las audiencias de cada virreinato. Se trataba de «la confusa proliferación de las leyes, los reglamentos y los decretos escritos, muchos de los cuales contenían reglas que especificaban los comportamientos requeridos con un detalle molesto (y a veces aparentemente lunático), y el fracaso de todos

5 «El sistema legal colonial no funcionaba para proteger los derechos entre los ciudadanos, incluso los ricos. Funcionaba para proteger el interés del rey y la prerrogativa real de intervención arbitraria en todos los casos. El despotismo y la legalidad burguesa pertenecen a épocas diferentes de la historia legal» (Coatsworth, Tortella, 58, 59). 
los intentos de codificación, lo que al dificultar y frecuentemente imposibilitar la determinación requería en efecto la ley escrita» [Coatsworth, Tortella (2007), 53]; todo esto era acompañado frecuentemente, en especial durante la época borbónica, por la ingerencia de la Corona para superar el caos judicial a favor de determinados gremios o intereses. De esta manera, se inicia una larga tradición de formalismo legal y de carencia de independencia de la Justicia que deja fuera de consideración los contenidos y objetivos mismos de la ley y que se aparta también de la lógica judicial requerida para prestarle coherencia y eficiencia al sistema legal.

Una vez liquidado el orden político colonial, el derecho tanto en España como en sus excolonias se orientó por la tradición francesa de ley civil que refleja el fuerte poder del ejecutivo y que tiende a otorgar poca autonomía y discreción a los jueces, presta menos énfasis a la defensa de los derechos de propiedad privada y, en cambio, protege y fortalece los derechos del Estado (Levine, 2005). Pero la intrínseca debilidad del Estado en América Latina dio lugar a un sistema legal que no era capaz siquiera de defender sus derechos, ineficiente y tan extensivo que fomentó el ventajismo político. No hubo entonces un sistema de justicia de origen popular que fuera respetado por todos los agentes en su jurisprudencia y en sus fallos, de tal modo que el imperio de la ley era precario, al cual no se sometían, en especial, los gobernantes. Los fallos dependían de un juez susceptible a las presiones de las partes o del gobierno y no de jurados de conciencia escogidos al azar entre los ciudadanos, uno de los pilares de la independencia de la justicia en cualquier país o para que la justicia opere bajo un manto de ignorancia y como maquinaria que funciona sobre la base de unos principios aceptados.

El sistema político y legal que se estaba creando estaba lejos de ser «un sistema estable y bien especificado de derechos económicos y políticos que proporcionaron un compromiso cré́ble, prerrequisito necesario para mercados económicos eficientes» [North, Summerhill, Weinsgat (2002), 11]; por el contrario, acá el conflicto político y regional o los cambios radicales de reglas de juego constitucionales generaban un sistema inestable donde los derechos políticos de unos quedaban extinguidos cuando los otros alcanzaban el poder, y sus bienes podían ser expropiados, ya fuera en la forma de préstamos forzosos o de confiscación bienes para atender las necesidades de los grupos en armas. Más aún, derechos, favores y concesiones económicas concedidos por un gobierno eran anulados cuando era desplazado por el partido opositor, mientras que cambiaron también las atribuciones tributarias y legales de las circunscripciones regionales.

Emergió así en la América independiente una tradición constitucional de sucesión, mediante la cual un mandatario cambiaba las reglas políticas para perpetuar su partido o su persona en el poder [Loveman (2003), 300]. En un medio donde el poder legislativo era débil y la población creía en un mundo mágico, donde además había grupos armados que amenazaban la 
propiedad de los más, los hombres de propiedad cedían sus derechos en manos del caudillo autoritario que remplazaba la voluntad colectiva y se apoyaba en el carisma con que lo percibía la población ${ }^{6}$.

\subsection{La constitución de Cádiz}

El primer modelo constitucional que inspiró a muchas ciudades y regiones de las colonias de España en América, tras el derrocamiento de la monarquía por los ejércitos de Napoleón Bonaparte, fue el de las cortes de Cádiz, desde donde se erigió un gobierno en oposición al de la ocupación francesa. Las cortes españolas fueron el equivalente del parlamento inglés o los estados franceses, instancias de negociación entre los hombres pudientes de la época y el soberano, germen de la democracia liberal en occidente. Mientras que la revolución inglesa de 1688 y la francesa de 1789 reformaron y sometieron o destruyeron las monarquías absolutistas que los gobernaban, el parlamento español no logró hacer lo mismo al tiempo de la Independencia.

Las Cortes de Cádiz se constituyeron en septiembre de 1810 «verdaderamente como una asamblea nacional moderna» (Rodríguez, 155) que representaba todo el mundo español, incluyendo 30 representantes de los territorios de ultramar dentro de un total de 104. La composición de las Cortes era un tercio de eclesiásticos, una sexta de nobles y el resto personas del tercer estado o de las clases medias de la época. La constitución de Cádiz siguió el modelo de monarquía constitucional inglés, frente a los excesos de la revolución francesa que atemorizaban los espíritus liberales de la época. La Carta definió una nación española que le concedió derechos de ciudadanía no sólo a todos los peninsulares sino a los indígenas, mestizos y a los criollos de sus territorios de ultramar, pero se los negó a los africano-americanos en condición de esclavitud. La esclavitud misma no pudo ser abolida por la presencia de los poderosos intereses de las islas caribeñas, aunque hubo mociones de extinguirla progresivamente. Se creaban nuevas «naciones» que se autogobernaban, regidas todavía por un monarca pero limitado por el parlamento y debiéndole obediencia a la Justicia. Los ciudadanos quedaban dotados de garantías constitucionales en su vida, propiedad, libertad y seguridad.

Las Cortes introdujeron una división de poderes peculiar, en la que primaba la rama legislativa que sujetaba el poder del rey pero no del todo, mientras que el poder judicial recibió poca independencia. Se abolieron todas las instituciones señoriales de España y de sus reinos asociados, el tributo de indios, la mita y los trabajos forzados, al igual que la Inquisición

6 Véase John Lynch (2001), 20, donde afirma que para él Hobbes captaba mejor la esencia del caudillismo latinoamericano que cualquier autor moderno. 
para establecer un principio de separación entre Iglesia y Estado. Muy importante también fue la introducción de la noción de promulgar leyes en la nación española que aplicaban por igual a todos los ciudadanos, incluyendo a los de los reinos de ultramar.

Esta idea de la igualdad frente a la ley, sin embargo, sería una de las más difíciles de implementar en la larga historia de construcción de las endebles democracias liberales latinoamericanas. Por primera vez en la historia de América, la Constitución de Cádiz propició la inclusión de los indígenas y el voto masculino sin condiciones de propiedad ni de alfabetismo, algo que buena parte de las subsecuentes cartas locales y eventualmente nacionales tenderían a negar y que reaparecería intermitentemente durante la fase de las reformas liberales y del federalismo. La desigualdad intrínseca legada por la sociedad de castas organizada por los españoles se manifestó de manera caótica en el sistema legal.

La organización municipal y regional sufrió un vuelco al aprobarse la figura de los ayuntamientos constitucionales o consejos locales para poblaciones mayores de 1.000 habitantes, que remplazaban a los regidores hereditarios, y las diputaciones provinciales, dotados de un cuerpo legislativo de siete diputados y bajo el mando de un jefe político más el intendente; al mismo tiempo, las Cortes abolían el virreinato y transformaban las audiencias en tribunales supremos. Las provincias respondían ante el gobierno central español, provisionalmente localizado en Cádiz, mientras Madrid siguiera ocupada por las tropas francesas. El efecto más contundente fue el de extender el autogobierno a muchas poblaciones, lo que, según Rodríguez, «revolucionó a América al extender la participación política» [Rodríguez (2005), 168] y que fue un importante guiño a favor de la idea de un gobierno local autónomo.

El tema de propiciar el libre comercio mostró disparidad de intereses entre los españoles americanos y los europeos, pero en últimas la fuerza de los comerciantes del monopolio comercial de Cádiz, al lado de los intereses de algunos consulados americanos, dejaron las cosas como estaban, a pesar de que se contaba a Inglaterra como aliada en la contienda contra Bonaparte. Otros intereses de por medio, como el de los propietarios de obrajes que producían textiles y los beneficiarios locales del comercio monopolista español y los armadores locales de naves, que temían a la competencia por parte de las flotas de Inglaterra y Holanda, se opusieron todos al libre comercio. En contrario, los comerciantes de los puertos caribeños que venían lucrándose con el contrabando abogaban por la normalización de su actividad que bajo el libre comercio dejaría de ser delito.

Algo que legó la Constitución de Cádiz fue la idea de que «la soberanía reside en la nación», que es particularmente ambigua para evadir la noción más radical de que la soberanía nace de la voluntad popular. El rey no quedaba verdaderamente sujeto a la propia constitución, pues no se le podía exigir responsabilidad ni enjuiciarlo en caso de que la violara. «Más aún, se 
le concedió una autoridad ambigua y amplia para conservar el orden público,... lenguaje que también se haría común en las constituciones hispanoamericanas durante el siglo XIX, en cuanto se refiere a las atribuciones del poder ejecutivo». Al mismo tiempo, las Cortes tenían la atribución de suspender las garantías constitucionales para defender la seguridad del Estado, lo cual «sería modelo para futuros regímenes de excepción constitucional latinoamericanos» [Loveman (2003), 285].

Por último, la constitución gaditana proclamó que la legislación colonial contenida en la Recopilación de las leyes de Indias seguía vigente en tanto no estuviera en conflicto con la nueva constitución, maridaje con el viejo régimen que fue muy frecuente en el constitucionalismo andino, agregando otra fuente de incertidumbre a la interpretación de la ley. Poderes ejecutivos fuertes, gobiernos que no se ajustaban a la constitución y «conyugalismo jurídico» entre la nueva carta y el arcaico derecho indiano fueron entonces legados del constitucionalismo español del interregno bonapartista que adoptaron prácticamente todas las colonias latinoamericanas.

La restauración en el trono de Fernando VII y el reagrupamiento de los intereses señoriales y eclesiásticos a su alrededor condujeron a la abolición de las cortes de Cádiz y de su constitución en mayo de 1814, mientras que en las colonias se desataba desde antes la anarquía por la desintegración del orden político. En la Nueva Granada la influencia de la constitución gaditana fue limitada. Para la región Andina, sus «impactos concretos fueron muy relativos» [Loveman (2003), 283]. Así se pone de relieve el fracaso de la revolución democrático burguesa en llevar a cabo la modernización económica y la democratización política en el mundo hispánico, factores que ralentizaron el desarrollo económico tanto de España como de sus ex colonias durante el siglo XIX. Sin embargo, España no vivió de manera tan intensa la pérdida de su orden político como sus excolonias y pudo crecer más que países como Colombia durante ese período ${ }^{7}$.

\subsection{El constitucionalismo localista}

Las constituciones que proliferaron en la América española y en la Nueva Granada con la pérdida del orden político colonial fueron esencialmente localistas. Cada ciudad o provincia se creyó con derecho de darse su propia carta política y declarar su soberanía e independencia no sólo del rey de España derrocado por Bonaparte sino de las demás provincias y de la estructura administrativa virreinal heredada de España.

\footnotetext{
7 Según Coatsworth y Tortella, España se retrasó frente al ritmo de industrialización de los países avanzados entre 1800 y 1850 . En la segunda mitad del siglo XIX, el comportamiento español igualó al de Inglaterra y Francia. En promedio el PIB por habitante español aumentó 0,95 por cien anual entre 1820 y 1900 . En contraste, el PIB por habitante colombiano creció sólo al 0,25 por cien anual entre 1833 y 1905 (cuadro 1 ).
} 
No habiendo gobiernos parlamentarios en España, no podía haberlos tampoco en sus colonias, hecho que les impidió a los criollos contar con una visión proto-nacional y con un escenario de negociación política que transara los intereses de distintas ciudades, regiones, sectores económicos, etnias y gremios. La geografía complotaba también contra cualquier orden constitucional: enormes distancias entre escasos poblados dificultaba imponer un control militar sobre tan dilatados territorios. Así se fue diluyendo la Nueva Granada frente a los intereses de Cartagena, Bogotá, Vélez y otras provincias. Así también se disgregó la Gran Colombia ambicionada por Simón Bolívar con intereses contrapuestos en cada audiencia o capitanía frente a los de los «lanudos» del virreinato [Lynch (1976), 269 y 327]. Los criollos debieron aprender sobre la marcha a diseñar y cobrar impuestos, y a ejecutar gasto de acuerdo con transacciones políticas o prioridades económicas para financiar las guerras de independencia y para enfrentar el pago de la deuda externa que financió parte de ella.

Los conflictos que estallaron entre los distintos intereses locales, cuando aún no se había consolidado la independencia de España, ha sido caracterizado por la historiografía colombiana tradicional como "la patria boba», caracterización moralista ingenua que no puede entender que la carencia de una tradición democrático burguesa y parlamentaria fue la que propició que los intereses locales se salieran de madre cuando colapsó el orden político absolutista. La figura del cabildo abierto, que era un retozo democrático que se permitió de manera muy ocasional y necesariamente desordenada, era convocada por los criollos cuando conocían que el fervor popular se inclinaba a favor de sus intereses.

Entre las constituciones que se redactaron en la Nueva Granada por esta época destacan la de la ciudad de Cartagena, que fue la que más se acercó al espíritu que orientó a las cortes de Cádiz, absorbiendo los principios de la declaración de los derechos del hombre en su versión más democrática. La igualdad legal debería entenderse como «la igualdad de dependencia y sumisión a la ley de todo ciudadano, e igualdad de protección de la ley a todos ellos, de modo que la idea de hombres privilegiados hereditariamente debería juzgarse como absurda» (Martínez, 2006). Sin embargo, la constitución cartagenera no afirmó la igualdad de todos los hombres frente a la ley porque no cuestionó la esclavitud (Urueña, 2008).

Ninguna contribución o impuesto podría ser fijado sin el consentimiento de la Legislatura, lo cual es de la esencia del régimen democrático burgués. La idea de igualdad, sin embargo, no fue acompañado del principio de la soberanía del individuo, que es la que le permite escoger y decidir, de acuerdo con su conciencia, sobre política, religión y su condición civil. Los criollos abrazaron la Ilustración europea pero no alcanzaron a cuestionar los dogmas católicos, desconocían la Reforma Protestante, que entendían como diabólica, y estaban lejos de la experiencia europea de dos siglos de guerras religiosas, que había rendido necesario en todas las cartas surgidas 
de la revolución democrático liberal hacer una tajante separación entre Iglesia y Estado: que ninguna religión pudiera capturar cargos o el estado mismo y ejercer un monopolio sobre las conciencias de los ciudadanos.

«En el mundo hispano... la constitución ordena políticamente una sociedad de católicos, una ecclesia con forma de nación en la que quienes cuentan son los feligreses. No otra es la razón de que las normas electorales hablen casi siempre de almas, que la condición del individuo activo políticamente sea la del vecino y que la circunscripción básica sea la parroquia» [Portillo, J. M. (s.f): «Constitución», Universidad del País Vasco, Universidad de Santiago de Compostela].

El tema de la igualdad racial se derivaba de los principios igualitarios de la Ilustración que aplicaban a toda la humanidad, pero los criollos siguieron pensando en las castas de la manera como habían sido concebidas por el derecho indiano: los indígenas como "personas rústicas o miserables, necesitadas de protección y tutela» [Ots y Capdequi (1969), 245], o se hablaba también de «las tribus salvajes» [Samper (1982), 46], los negros como raza para el trabajo sin que ganara la idea de su liberación, las mezclas raciales contaminadas por sus componentes y los criollos de sangre impoluta como condición de privilegio político y económico. En contraposición a la libertad de conciencia, la Constitución de Cartagena acogió a la Religión Católica «como la única verdadera y la Religión del Estado», declarando que no se permitiría ningún otro culto público ni privado, aunque los extranjeros no serían molestados "por el mero motivo de su creencia». Se le reconocían a los extranjeros derechos de conciencia que se les negaban a los ciudadanos de Cartagena.

La Constitución de Cundinamarca de 1811 se apartó de la orientación moderna recibida por la Constitución de la nación española, acordada en Cádiz. La provincia esperaba de alguna manera que «el rey a su ingreso al trono jurará sostener y cumplir esta constitución» como base fundamental de gobierno. También los constituyentes de la provincia redactan una carta que «reconoce y profesa la Religión Católica, Apostólica y Romana, como la única verdadera» y como "la única Religión de este Estado», al punto que se comprometió a no permitir otro culto público ni privado» (Martínez, 2006). «La Declaración cundinamarquesa tomó por principal molde... la Declaración de derechos de la Constitución francesa de 1795 (termidoreana)... (aunque) los constituyentes santafereños no parecen haber aceptado su orientación liberal y tolerante» (Urueña, 2008).

El origen de la soberanía cundinamarquesa era notablemente oscuro: ésta "reside esencialmente en la universalidad de los ciudadanos» [Samper (1982), 40]. Se hacía evidente en ella un espíritu temeroso de las libertades públicas: "Fueron prohibidas las "corporaciones y asociaciones contrarias al orden público", las sociedades denominadas populares, las solicitudes 
formuladas colectivamente, la reunión de gentes armadas ("atentados contra la seguridad pública") o sin armas ("serán dispersadas primero por una orden verbal, y si no bastare, por la fuerza"), y hasta las deliberaciones de autoridades constituidas en reuniones no prescritas por la ley. Las profesiones "que interesan a las costumbres públicas, a la seguridad, y sanidad de los ciudadanos", quedaron bajo la supervisión de la ley. Se insistió en la protección de la propiedad... y se garantizó la inviolabilidad de todas las propiedades y la "justa indemnización de aquellas cuyo sacrificio pueda exigir la necesidad pública legalmente manifestada" ». En términos de división de poderes había una fuerte inclinación a favor del ejecutivo, en cabeza del Rey y de sus ministros que debían explicar sus actos ante un senado. La legislatura contaría con un representante por cada 10.000 habitantes y se rotaría la mitad cada año o sea que se estaba en un estado electoral cuasipermanente. Los requisitos para poder elegir eran de ser varones libres, mayores de veinticinco años, cabezas de familia, que vivan de sus rentas ú ocupación sin dependencia de otros, siendo juzgados por el cura del lugar de cumplir con los requisitos, lo cual dejaba por fuera de la participación política a la mayor parte de la población.

Sabiéndose provincia, Cundinamarca llama a la organización de un «Congreso Nacional compuesto de todas los Representantes que envíen las expresadas Provincias, adoptando para su justa proporción la base, ó de territorio ó de populación...pero que por ningún caso se extienda á oprimir á una ó á muchas Provincias a favor de otra ú otras». La constitución fue promulgada en abril de 1811 y sería un ensayo propositivo antes que un conjunto de reglas para un país que distaba mucho de existir.

Camilo Torres alcanzó a plantear un Acta de Federación de las Provincias Unidas de la Nueva Granada que fue el antecedente constitucional más importante para la idea federal dentro del territorio que eventualmente ocuparía Colombia. El Acta rechaza tanto la monarquía bajo cabeza de Fernando VII, como también las cortes de Cádiz, alejándose así de la visión gradualista de la Constitución de Cundinamarca y planteándose la necesidad de una relación equilibrada entre un centro político y las regiones que constituían un proyecto de nación. El Acta replicaba la división de funciones entre los estados y el gobierno federal de que hacía gala la constitución de los Estados Unidos de América, en perfecta oposición a la constitución de Cundinamarca. Las provincias se encargaban de darse un gobierno popular con una división de poderes que le daba el control político y económico de sus regiones, a la vez de un sistema de justicia federada. Explicitaba que daría "protección y fomento de la agricultura, artes, ciencias, comercio y cuanto pueda conducir a su felicidad y prosperidad».

Los ingresos del gobierno central estarían dados por impuestos y las contribuciones requeridas para la defensa nacional. Los ingresos regulares provendrían de las aduanas, al tiempo que se debía fomentar el comercio y no gravarlo con nuevas contribuciones. Las casas de moneda también que- 
daban bajo jurisdicción del gobierno central. De esta manera se estableció la división de tareas entre un gobierno central, a cargo de las tareas comunes de defensa y fomento del comercio intra-provincial, y uno provincial que tenía bajo su responsabilidad la administración económica de la subregión. El acta aprobado en noviembre de 1811 no contó con la rúbrica de la representación de la Provincia de Cundinamarca que tenía aspiraciones centralistas, lo cual unido a las guerras intestinas que estallaron seguidamente y a las circunstancias de la guerra con España le impidió tener efectos perdurables.

La guerra de independencia obligó a una centralización de recursos y del poder político que sentaron algunas de las condiciones para desarrollar una organización política relativamente coherente y un sistema de justicia que fue perdiendo muchos de sus rasgos originales. Los militares y en particular el caudillo Simón Bolívar entraron a jugar un papel dominante que fue combatido en particular por los políticos colombianos que contemplaron con preocupación la concentración de todos los poderes en la persona del Libertador. Éste tendía a exigir una obediencia absoluta a los legislativos que se iban creando, en contraste, por ejemplo, con la obediencia que mostraron los militares norteamericanos al congreso continental en su guerra de independencia ${ }^{8}$. En efecto, durante la fase termidoreana liderada por Bolívar se restablecieron la mayor parte de los impuestos coloniales abolidos, se abandonó el ensayo del impuesto directo y se aplazó la liberación de los esclavos. La lucha se zanjó a favor de los santanderistas en el caso de la República de la Nueva Granada, que surgió como tal después de la disolución de la Gran Colombia en 1830, dando al traste con otro de los sueños del caudillo libertador de ser conductor de un gran imperio americano [Rodríguez (2005), 407 y 408].

Uribe-Urán encuentra un largo período de gobiernos aristocráticos entre 1837 y 1849 de virtual empate entre sectores provinciales y más tradicionales [Uribe-Urán (2000), 117] que se despeja durante la primera administración reformista de Tomás Cipriano de Mosquera. Comenzaron a aflorar entonces dos visiones contrapuestas de lo que debería ser la organización política nacional: un régimen de carácter laico, de mínima intervención en la economía que fomentara el comercio exterior y con igualdad al menos frente a la ley, por parte de los liberales; o una organización que mantuviera los rasgos fundamentales de la herencia española, en particular su régimen centralista e interventor, ligado estrechamente con la Iglesia católica, que continuara con los monopolios a las actividades más transables de la época y que sostuviera a las castas en su lugar original. Eventualmente surgirían los dos partidos que defenderían cada tipo de organización de mane-

8 Así, el comandante del ejército norteamericano que derrotó a los ingleses, George Washington, fue un fiel observante de las leyes trazadas por los congresos continentales y del principio de la subordinación del poder militar al poder civil [Elliot (2007), 394]. 
ra ahincada, dando lugar a fuertes movimientos pendulares de las constituciones a lo largo del siglo, surgidas de guerras civiles generalizadas, como fueron las de 1839, 1862 y 1885.

\section{LAS CONSTITUCIONES REPUBLICANAS}

El período 1810-1829 es de de natural inestabilidad y transición dadas las guerras de independencia que sufrieron la mayor parte de los países de América Latina. Pasada esta transición, la inestabilidad aumenta entre 1830 y 1916, pero no sucede lo mismo en todas partes. En promedio, el período de cada constitución en el continente fue de sólo veinte años, pero para Colombia fue de menos de diez años. Los países del cono sur tuvieron en este período una sola constitución, mientras Colombia tuvo nueve. Entre 1810 y 1916, Colombia y Venezuela tienen los comportamientos más inestables de la muestra.

CUADRO 1 NÚMERO DE NUEVAS CONSTITUCIONES EN AMÉRICA LATINA

\begin{tabular}{|l|c|c|c|}
\hline \multicolumn{1}{|c|}{ País } & $\mathbf{1 8 1 0 - 1 8 2 9}$ & $\mathbf{1 8 3 0 - 1 9 1 6}$ & $\mathbf{1 8 1 0 - 1 9 1 6}$ \\
\hline Venezuela & 3 & 12 & 15 \\
Colombia & 4 & 9 & 13 \\
Argentina & 6 & 1 & 7 \\
Chile 6 & 1 & 7 & \\
Promedio & 2 & 6,6 & 8,6 \\
\hline
\end{tabular}

Fuente: Dye (2006), 178, 179.

Malcom Deas ha asociado las crisis de las exportaciones colombianas con la inestabilidad política del período, encontrando una correlación positiva entre estas y las guerras civiles [Deas (1993), 65]. Dos factores enunciados atrás destacan para explicar la anomalía colombiana: era una región donde las instituciones coloniales estaba sólidamente empotradas, dándole fortaleza a sus sectores conservadores, y su inserción en el mercado mundial no fue muy sólida, impidiendo la prosperidad generalizada que aplacara los espíritus pugnaces y permitiera la consolidación de una burguesía liberal. Ésta sería una verificación parcial de la hipótesis de Glaeser et al.

¿Qué intereses económicos estarían detrás de los que propugnaban por el federalismo y los que apoyaban el centralismo en Colombia? Se debe considerar primero que los intereses económicos en la Colombia del siglo XIX están poco delineados, pues no había ocurrido una especialización del trabajo y de funciones, de tal modo que coinciden terratenientes que comercian o prestan dinero, quienes militan en ambos partidos. Sin embargo, es 
claro que los beneficiarios del federalismo serán precisamente los comerciantes y pequeños financistas, para quienes el monopolio comercial del Estado y el monopolio del crédito de la Iglesia impedían desarrollar sus actividades. Sin embargo, los grandes comerciantes encontrarían contraproducentes las barreras al comercio que se erigieron durante la fase federalista. Entre tanto, los terratenientes tendrían más influencia a nivel estadual para extender su propiedad mediante el remate de las tierras públicas que bajo el sistema centralista que las entregaba a los agiotistas más poderosos como colateral. Los deudores de la Iglesia también se vieron beneficiados por la amortización de manos muertas pues disminuyeron sus acreencias a la mitad.

Los que apoyaron el centralismo y el status quo fueron los esclavistas y los acreedores del gobierno, quienes en medio de márgenes altos de riesgo alcanzaron a obtener utilidades y aspiraban a que el gobierno pudiera cumplir sus compromisos ${ }^{9}$. Se le suman los sectores que pretendían mantener el legado colonial: artesanos que exigían protección arancelaria y que lo obtendrían, más no para satisfacerlos sino para conseguir recursos fiscales, y los sectores identificados con la Iglesia que rechazaban que esta fuera expropiada y debilitada ${ }^{10}$. Por último, los sectores deudores que debieron ser escasos serían amigos de las políticas monetarias laxas, mientras que los acreedores buscarían políticas basadas en el patrón oro o en el rigor monetario.

Los indígenas sabían que las instituciones provistas por la Corona y que alguna protección les ofrecían, como la propiedad comunitaria sobre los resguardos y los controles a los abusos de su mano de obra, serían desmanteladas por las reformas liberales del partido independentista, por lo cual se tornaron en fervientes realistas. Los esclavos en algunos casos le dieron la bienvenida a la Independencia porque les prometía la libertad en una generación, y aún inmediata para los que participaran en la contienda, pero ofertas similares vinieron del lado realista. Al final de las contiendas, los

9 «La deuda pública estuvo asociada fatalmente con otras dos instituciones; la guerra civil y el caos monetario. El entrelazamiento de estas instituciones ineficientes conformó un escenario en el que gobiernos, grupos políticos, comerciantes, agiotistas, banqueros, entre otros, encontraron una fuente certera de financiación, ganancias de fácil realización y una poderosa arma de partido» [Rojas (2004), 34]

10 En la literatura norteamericana sobre los intereses económicos que le dieron forma a la Constitución más centralista de 1787 se destaca a los financistas del gobierno que esperaban que este implementara impuestos adecuados sobre la propiedad para pagar su deuda. «Comerciantes, prestamistas, poseedores de bonos públicos, manufactureros, armadores de barcos, capitalistas y financistas eran simpatizantes de la Constitución. Ellos se beneficiarían de una mayor certidumbre en las reglas de comercio, intercambio y mercados crediticios bajo la Constitución». Los beneficiarios de la federación más suelta eran los propietarios de inmuebles, propietarios territoriales y pequeños campesinos endeudados porque tenían «una mayor capacidad de evadir la pesada tributación para pagar la deuda pública y para promover políticas monetarias laxas y leyes que permitieran posponer el pago de las deudas privadas (moratoria de deudas)» [McGuire, Ohsfeldt (1986), 82]. 
esclavos se encontraron en una situación no muy distinta a la inicial: sus personas eran todavía propiedad privada y sus hijos debían prestarse a concierto hasta los 18 años para amortizar los costos de su liberación.

Las fuerzas localistas y regionales que desató la Independencia fueron contenidas por las necesidades militares de los criollos. La guerra de liberación obligó a centrar todos los esfuerzos en fortalecer el ejército y con ello a centralizar el incipiente Estado. Una vez expulsados los españoles del territorio que se vendría a denominar La Gran Colombia, pero todavía con un poder realista amenazante en territorio peruano, Venezuela aprobaría su constitución de Angostura en 1819, muy influida por Simón Bolívar, que le introdujo fuertes rasgos dictatoriales. Entre éstos figuraban la división de los ciudadanos entre activos y pasivos (sin derecho a elegir o ser elegidos), acreditar propiedad de 500 pesos para los activos, mientras que el presidente concentraba todos los poderes, pudiendo incluso invalidar sentencias judiciales y nombrar su sucesor. Existía un senado hereditario y un poder moral compuesto por un presidente y 40 destacados ciudadanos que ejercerían censura educativa, llamado el Areópago ${ }^{11}$. La disyuntiva de los criollos dirigentes frente al republicanismo eran, según Urueña, las siguientes:

$¿$ Es posible instaurar un gobierno republicano en un territorio extenso, de población racialmente heterogénea, de bajo nivel de instrucción y civismo, acostumbrada a la tiranía, sin experiencia en la ciencia de gobierno y, además, cargada con un pasado de odios interraciales? ¿Es posible en esas condiciones inéditas establecer un gobierno que logre conciliar igualdad, libertad y justicia en el marco de un orden legítimo? [Urueña (2004), 69].

La Constitución de 1821 se inspira en el derecho divino como fuente de soberanía: reconoce la religión católica como única verdadera que acoge y protege. Los ciudadanos deben saber leer y escribir a partir de 1840 para participar en elecciones, lo cual fuera de restrictiva, reconoce un problema de analfabetismo generalizado, pero además deben tener un patrimonio de cien pesos o en su defecto una profesión que les permitiera la independencia, excluyendo de la ciudadanía a jornaleros, arrendatarios y sirvientes. Había un sistema de votación indirecto, mediante electores can-

11 «Ya que no debemos mezclar la forma monárquica con la popular que hemos adoptado, debemos, por lo menos, hacer que haya en la República un cuerpo inalterable (el Senado hereditario, con su Poder neutro) que le asegure su estabilidad; pues, sin estabilidad, todo principio político se corrompe y termina siempre por corromperse... yo tengo muy poca confianza en la moral de nuestros conciudadanos, y sin moral republicana, no puede haber gobierno libre. Para afirmar esta moral, he inventado un cuarto poder [Poder moral] que críe a los hombres en la virtud y los mantenga en ella. También este poder le parecerá a Ud defectuoso; mas, amigo, si Ud quiere República en Colombia, es preciso que quiera también que haya virtud política» (Carta a Guillermo White, mayo 26 de 1820). Citado en Urueña (2004, 213-214). 
tonales cuyos requisitos de propiedad y sapiencia eran mayores aún. Ellos conformaban asambleas electorales que elegían presidente, senadores departamentales y representantes de provincia o sea que se daban un cuerpo legislativo dividido en dos, donde la cámara contaba con representantes que ejercían por cuatro años, mientras que los senadores tenían períodos de ocho años y se cambiaba la mitad cada cuatro años (Restrepo Piedrahita). Santander abolió la inquisición, limitó la censura religiosa y abogó por un sistema educativo basado en el utilitarismo benthamista [Gargarella (2005), 240].

La pugna fundamental en los años de la post independencia en los países liberados por Simón Bolívar fue la de establecer formas de gobierno centralistas con un enorme poder concentrado en la presidencia vitalicia del propio Bolívar, quien además podía nombrar a su sucesor, combinado con restricciones de ciudadanía a los que no contaban con propiedad o no sabían leer y escribir, contra unos gobiernos más liberales que contaban con reglas menos restrictivas de participación política.

En el cuarto de siglo que sucedió al Congreso de Cúcuta, la reacción en contra de la ruptura con el orden colonial se hizo cada vez más patente. Los dos puntos críticos en este proceso fueron la reacción bolivariana de fines de los años veinte (dictadura 1828-1830), que fuera seguida por la derrota de sus aspiraciones, la aprobación de la constitución de 1830 y la elección de Santander a la presidencia, quien sin embargo no pudo profundizar las reformas liberales. Santander gobernó hasta 1837 cuando comenzó a abrirse la primera gran conflagración civil de la vida independiente, la Guerra de los Supremos (1839-1842), que correspondían a los cuatro caudillos esclavistas de la región caucana, quienes dominaron la política colombiana hasta la década del setenta. Detrás de la primera confrontación civil, aparentemente por motivos religiosos, estaba subyacente la aspiración de cada región por más soberanía de la que había podido disfrutar hasta el momento, algo que demostraría ser imparable una década después (Ocampo, 1993).

El proceso de reforzamiento de las instituciones legadas por España se interrumpió a mediados de la década del cuarenta, dando paso a un rápido proceso de reforma durante el gobierno conservador de Tomás Cipriano de Mosquera (1845-1849) y del liberal de José Hilario López (1849-1853). Se llevó a cabo entonces unas reformas profundas, que comprendieron la abolición total de la esclavitud, la autorización a las provincias para arreglar la repartición definitiva de los resguardos, la redención de los censos eclesiásticos y una reforma fiscal que concentraría los impuestos en las importaciones. Fue una fase en la cual cayeron sustancialmente los impuestos por habitante, dejando una mayor parte del ingreso disponible para el consumo o para la inversión, aunque esta quedaba restringida a una parte pequeña de la población y se destinaría a desarrollar actividades de exportación.

El mayor beneficio inmediato de la Independencia fue la reducción de los impuestos. Éstos pasaron del 12,5 por cien a menos de 5 por cien del 
PIB, lo cual fue una de las grandes ganancias que cosecharon los criollos con la Independencia. Tener a disposición del sector privado más de 7,5 puntos del PIB que sostenían la administración colonial, los gastos de defensa de Cartagena y el culto de la Iglesia debió tener un impacto apreciable sobre el consumo de los criollos. A largo plazo, sin embargo, el Estado demasiado pequeño sería un obstáculo a la paz política y al desarrollo económico, siendo incapaz de proveer bienes públicos indispensables como los medios de transporte, la educación y la higiene ${ }^{12}$.

La inversión no se desataría con fuerza hasta que se liberaran las trabas al comercio exterior, en particular el estanco del tabaco que siguió siendo de las rentas más altas con que contó el nuevo estado republicano. Se mantuvieron los monopolios que tasaban además del tabaco los consumos de aguardiente y sal, este último muy regresivo y que sería aumentado durante la segunda mitad del siglo XIX. En últimas, no podía haber crecimiento económico sostenido en cuanto no se restableciera una estabilidad política basada en unas reglas consensuadas, al menos entre los grupos dirigentes de la sociedad, y se permitieran y defendieran las actividades productivas que venían surgiendo difícilmente dentro del sector privado.

En 1848 se abolió el estanco del tabaco para permitir su exportación por parte de tres empresas criollas que permitió un auge exportador que se mantendría por dos décadas [Molina (2003), 297]. Se suprimieron los sistemas de arancel para sustituirlos por un sistema de tarifas aduaneras unificado, a lo cual se sumó la reducción de las alcabalas internas y externas al comercio. Se logró así un sistema simple y de bajos costos de recaudación, fundamentalmente concentrado en los impuestos a las importaciones, a pesar de la ideología librecambista de los liberales. Los altos impuestos a las importaciones eran la única fuente viable de recursos fiscales, en tanto combinaban ocultamiento y no molestaban a los productores locales, antes bien los protegían, y no afectaban tampoco a los exportadores de materias primas. Esto es algo que se repite para toda la América Ibérica y que llevó a que la región fuera la más proteccionista del mundo desde la Independencia (Coatsworth, Williamson, 2004). Las razones de fondo remiten a la pobreza generalizada, a la escasez de comercio exterior y a la debilidad del Estado que, a su vez, reflejaba la falta de democracia en el continente, en especial la ausencia del principio de tributación con representación.

Mientras los conservadores abrogaban por un control de la tributación por parte del gobierno central, los liberales trataron de fortalecer las finanzas de los estados soberanos y de los municipios, aduciendo, como evidentemente se pudo demostrar, que los contribuyentes estaban más dispuestos

12 «Las sociedades con grados de desigualdad extremos, como lo son la mayor parte de las que constituyen la América Latina, se desarrollaron de tal modo que contaron con muy pocos recursos públicos para apoyar el desarrollo económico, especialmente al nivel local» (Sokoloff, Zolt, 2007). 
a aportar recursos si los beneficios de su gasto les revertía de alguna manera. Pero el centro de gravedad de la sociedad legada por España era el centralismo que fue ocupando los espacios principales tanto de la tributación como del gasto e induciendo al contribuyente a evadir sus responsabilidades, en tanto pensaba, con buena razón, que los recursos no iban a ser gastados en su beneficio ni tampoco para el bien común sino para reproducir el partido en el poder.

El impuesto directo a nivel nacional fue propuesto varias veces, pero nunca hubo la organización requerida para que los ciudadanos declararan sus patrimonios, algo que era arriesgado en tiempos de turbulencia política, y que facilitaba que fueran sujeto de préstamos forzosos o expropiaciones. El impuesto directo tuvo alguna presencia a nivel municipal pero en tiempos del federalismo y tuvo vigencia en los estados soberanos de Cundinamarca, Santander, Panamá y Tolima, donde se elaboraron los catastros de propiedades inmobiliarias [Deas (1993), 82]. De este modo, el grueso de los ingresos fiscales surgió del impuesto al comercio de importación y de pesados impuestos a la sal y al degüello de ganado, castigando a los consumidores más pobres (Junguito, 2007).

\subsection{LA CONSTITUCIÓN FEDERAL DE 1863}

La constitución de los Estados Unidos de Colombia sellada en Rionegro en 1863 fue resultado de la guerra ganada por Tomás Cipriano de Mosquera, donde se coartaron las posiciones ideológicas del partido conservador, aunque éste había evidenciado simpatía a favor de dividir el poder de manera geográfica, para garantizar sus creencias frente a la hegemonía liberal. La constitución surgió como un pacto de regiones, tal como rezaba su texto: "(estas) se unen y confederan a perpetuidad consultando su seguridad exterior y recíproco auxilio auxilio y forman una Nación libre, soberana e independiente, bajo el nombre de "Estados Unidos de Colombia"».

Lo específico del sistema federal es la separación de poderes territoriales, que genera un equilibrio entre municipio, región y centro político. En términos históricos, el federalismo y la división de poderes explican la dificultad que tuvieron los gobiernos de Occidente para expropiar la riqueza de sus ciudadanos y, así mismo, para favorecer su sistemático desarrollo económico (Weingast, 1995).

Weingast ha formulado la manera cómo el sistema federal se constituyó en un sistema auto-equilibrado que propició el crecimiento económico de largo plazo en varios países del mundo que llama «federalismo preservador de mercado», y que no aplica necesariamente a muchos países que se autodenominan como federales. Weingast define unas características para este federalismo progresivo que incluyen el freno al autoritarismo, que contribuye a la defensa de los derechos de propiedad de los ciudadanos, el soste- 
nimiento de un orden político consensuado y competencia económica entre regiones, ellas mismas responsables de su manejo económico y blindadas contra el financiamiento por medio de la emisión inflacionaria.

Los estados soberanos en el caso colombiano se confederan pero con una enorme desconfianza frente al poder central, conociendo de las experiencias militares caudillescas del pasado. Si en las constituciones anteriores era evidente la carencia de una división de poderes, ahora la organización constitucional se iba en contra y dividía tanto el poder que destruía su centro neurálgico: la arquitectura acogida entrega todo el poder a los estados soberanos. La constitución podía ser suspendida cuando «hubiera conmoción interna que afectara la paz pública», de tal modo que el autoritarismo no está controlado por la división de poderes. Así mismo el artículo 91 permitía «declarar la guerra interna contra la resistencia de la autoridad Federal» [Loveman (2003), 304 y 305] o sea de nuevo la desobediencia frente a la ley existe como prerrogativa constitucional.

No habría entonces árbitro (el ejecutivo actuando en derecho) para conciliar diferencias entre los estados soberanos ni monopolio de los medios de violencia en manos del Estado. Por el contrario, los estados soberanos tendrían guardias militares más fuertes que las de la «Unión» y se otorgaría libertad absoluta para el porte y comercio de armas. Aún dentro de los estados soberanos proliferaron los ejércitos temporales de los señores de la guerra al lado de las guardias estaduales. No hubo entonces una cooperación, primero entre los partidos políticos, y segundo entre los estados soberanos con el gobierno central, para establecer un sistema auto-reforzado de compromisos a favor de impedir el conflicto u obligar a su transacción política [Kalmanovitz (2006), 108].

La debilidad de la presidencia nacional se refleja en su período de sólo dos años, que imposibilitaba desarrollar un programa de gobierno coherente, mientras que los presidentes de los estados soberanos y alcaldes era más sensato, de cuatro años; se prohibía la re-elección en todos los casos. El poder judicial era igualmente débil y fraccionado. Su cúpula estaba conformada por cinco magistrados y ningún Estado podía repetir, dándose un origen territorial pero no estricto de los magistrados. Sus períodos eran de sólo cuatro años, mientras su designación pasaba por la legislatura de cada Estado y después por el Senado, proceso que reflejaba politización, debilidad e independencia precarias. La consecuencia fue que hubo escasa confianza en la justicia como tercera parte imparcial, acentuada por el predominio del partido liberal ${ }^{13}$. El fraude liberal contrarrestaba de esta manera la dogmatización católica del electorado.

13 Esto se replicaba en el poder electoral cuando generaba reglas ventajistas sobre las elecciones y el conteo de votos, costumbres electorales que se tildaron de «sapistas» en los años setenta, derivadas del apodo que se le dio a un político bogotano reputado de tramposo electoral, Ramón Gómez; se acuñó entonces el lema «el que escruta elige». 
El sistema electoral estaba caracterizado por la dependencia de los electores de los hacendados y caciques políticos de los pueblos que arriaban a sus arrendatarios y peones a votar, ejercían violencia en los campos y compraban los votos en las pequeñas ciudades de la época. La introducción del voto universal masculino en un medio tan atrasado cultural y educativamente facilitaba a la Iglesia extender su influencia sobre los electores, lo que explica que el Partido Conservador apoyara el sufragio universal, una vez tomó conciencia del hecho, cuando el conservador Ospina fue elegido en la primera contienda presidencial de 1858 en que se permitía el sufragio masculino universal. Los liberales entonces se quejaron de que el pueblo ignorante era dominado por los curas y se tornaron más cautos con la democracia electoral.

Las reformas a la constitución requerían aprobación en la legislatura estatal, más discusión por ambas cámaras y ratificación unánime por el senado de plenipotenciarios, de tal manera que era como si los constituyentes iniciales hubieran tirado la llave al mar que permitiera reformar la constitución, adaptarla a los cambios económicos y políticos o negociar algunos de sus aspectos más molestos con la oposición. Este era otro incentivo para la guerra.

Los conflictos entre los estados soberanos con diferente partido gobernando condujo no sólo a guerras entre ellos sino también a que se impusieran aduanas y peajes que dificultaban la conformación de un mercado interior. Para Camacho Roldán, los sobre aranceles limitaban el comercio inter estadual, «dividiendo la república en pequeñas Chinas, con sus murallas de recaudadores y guardas» [citado en Deas (1993), 85]. En este sentido, el federalismo colombiano tendió más a separar que a unificar las distintas regiones del país y fue, por tanto, un obstáculo para el desarrollo económico de largo plazo.

La constitución defendía «La profesión libre, pública o privada, de cualquier religión; con tal que no se ejecuten hechos incompatibles con la soberanía nacional, o que tengan por objeto turbar la paz pública», algo que estaba dirigido expresamente contra la Iglesia Católica. Mosquera decretó la amortización de los bienes raíces o "manos muertas» de la Iglesia en 1861, socavándole sus apoyos materiales y permitiéndole al gobierno rematar las hipotecas o propiedades censadas a sus dueños por la mitad de su valor y vender a menos precio muchas propiedades que profundizaron el mercado de tierras (Jaramillo, Meisel, 2007).

La extensión del voto universal masculino entre los años cincuenta y 1880 produjo retozos democráticos, al ampliar la participación de los artesanos y otras capas medias en la política, que impulsaron con fuerza sus intereses separándose de los políticos liberales y enarbolando algunas ideas socialistas. La dictadura del general Melo en 1854 apoyó los intereses de los artesanos, quienes trataron de que los gobiernos liberales protegieran sus actividades de la competencia externa pero fueron derrotados por una 
alianza bipartidista que impuso el librecambio [Gutierrez (1995), 195]. Los artesanos fueron interpelados por el protoconservador Rafael Núñez de 1880 en adelante, quien les prometió protección consiguiendo un apoyo urbano popular para sus propuestas centralistas.

El conflicto electoral se acrecentaba porque no había documento de identidad aceptado por todos y eran los jueces de escrutinio los que tenían que validar la identificación del votante. Los efectos de la violencia electoral fueron notorios a lo largo del siglo XIX:

«En los municipios y caseríos donde las elecciones desembocaban en conflicto violento, sus poblaciones vivían en una atmósfera de temor e intimidación. En los casos más serios, como sucedió en Ciénaga en 1875 o en Bucaramanga en 1879, familias completas se veían forzadas a emigrar. Dondequiera que ocurriese, la violencia electoral dejaba detrás una herencia de odio partidista y, por consiguiente, alimentaba los deseos de venganza. Por encima de todo, la violencia electoral obstruía la consolidación del orden político, disminuyendo así el poder de un Estado de suyo débil» (Posada Carbó, 1996).

La práctica disolución del ejército nacional por los liberales impidió que éste actuara como árbitro de la política, mientras que las guardias de los estados soberanos se les incentivaba a actuar en favor del color político dominante. El ejército nacional se incrementó a partir de 1880 bajo la fórmula regeneradora de Rafael Núñez, pues según él y en ello tenía razón, se necesitaba un ejército nacional fuerte y único para reimponer el orden político perdido.

Todavía bajo un sistema federal, la política fue gravitando de vuelta hacia la matriz institucional original: recentralizando el poder a expensas de los gobiernos regionales y locales. Esto se hace evidente cuando se mide el papel de cada nivel de gobierno en el recaudo tributario total, que en esta fase está estrechamente asociado al gasto.

El gobierno central se debilita al pasar de 92 por cien del recaudo en 1845 al 48 por cien en 1870, ganando tanto los estados soberanos como los municipios. Es bien interesante el fortalecimiento municipal que pasó de acopiar 5 por cien del recaudo en 1845 al 22 por cien en su florecimiento de 1870. La Regeneración no toca tanto la participación de los Estados soberanos pero va a debilitar la célula municipal del organismo político y ¡de qué manera!, pues la devuelve al mínimo nivel de 1845.

Lo que mostró repetidamente el constitucionalismo colombiano fue una muy escasa división de poderes en el constitucionalismo conservador y excesiva para el liberal, que hizo poco por limitar la tiranía o impedir la vulneración de derechos de propiedad u ofrecer garantías a la oposición política; por lo menos, en el caso del federalismo que terminó siendo apoyado por muchos conservadores, hubo una división del poder geográfico y un 
empoderamiento del municipio. En ninguno de los dos se dio un equilibrio adecuado entre los tres poderes que se limitaran mutuamente y que permitiera alcanzar acuerdos de largo plazo entre los intereses regionales, religiosos y económicos sin hacerse trampa, recurrir a las vías de hecho o a la violencia para zanjar los intereses encontrados. Era un sistema que ofrecía pocas garantías para que la oposición pudiera ganar las elecciones, constituyendo así poderosos incentivos para la guerra.

\section{EL PROCESO DE CENTRALIZACIÓN POLÍTICA}

\subsection{La constitución de 1886}

Los liberales se alzaron en 1885, siendo derrotados por el gobierno de Núñez, que procedió a declarar extinguida la Constitución de 1863 y convocó una asamblea constituyente donde escasearon los representantes del partido liberal, lo que de nuevo le restaría consenso y legitimidad a la nueva constitución. La soberanía del Estado no partía de los otrora estados soberanos, sino que «reside esencial y exclusivamente en la Nación» (artículo 2). Partiendo de este concepto heredado de la constitución gadetana, Caro logró derivar un origen divino del poder al hacerle decir a la Carta en su artículo 28: «La Religión Católica, Apostólica, Romana, es la de la Nación; los Poderes públicos la protegerán y harán que sea respetada como esencial elemento del orden social». De esta manera, se liquidó la idea de soberanía popular, siendo remplazada por las nociones de autoridad ilimitada derivada de Dios que, por tanto, exige obediencia absoluta no tanto de los ciudadanos sino de los súbditos.

El monopolio religioso fue acompañado también de un monopolio político concentrado en una presidencia imperial, cuyo período era de seis años, con re-elección después de un período. El presidente era elegido indirectamente por ciudadanos con requisitos de alfabetismo, renta de anual de 500 pesos o propiedad de $\$ 1.500$. Hacia 1890 el ingreso por habitante del país era de $\$ 33$ pesos, quince veces el límite de participación política, y la inflación estaba perturbando todas las medidas económicas, mientras que el analfabetismo en 1900 era más del 65 por cien de la población (Ramírez, Salazar, 2007).

El poder regional quedaba abatido, pues el presidente nombraba y separaba libremente a los gobernadores y éstos a los alcaldes. El presidente nombraba también los magistrados de la corte suprema y de los tribunales superiores de ternas presentadas por la corte suprema. Se nombraban jueces de escrutinio que actuaron a favor del gobierno, cerrando así las vías electorales a la oposición, lo que incitaría al partido liberal a recurrir a dos nuevas guerras civiles (1895 y 1899-1902). En general, la constitución limitó fuertemente los derechos individuales y de expresión, y no sólo por lo que 
decía el texto constitucional, sino que podía recurrir al estado de sitio, que suspendía las escasas garantías individuales que otorgaba cada vez que lo considerara necesario, lo cual en efecto se hizo durante la mayor parte de los gobiernos de la Regeneración.

La cámara de representantes tenía período de cuatro años, mientras que el senado de seis años era elegido por las asambleas departamentales. Las elecciones más importantes, como la de presidente y congreso, se hacían en forma indirecta, por medio de electores, uno por cada mil individuos, pudiendo el gobierno hacer elegir personajes que nunca habían estado en el departamento que decían representar. Los ciudadanos sólo elegían directamente consejeros municipales y diputados a las asambleas. El legislativo era muy débil, pues se podía reunir cuatro meses cada dos años. De esta manera no había división de poderes geográfica, al abolir las elecciones por gobernadores y alcaldes, ni de un legislativo o judicial dotados de fuerza que pudiera neutralizar los abusos del poder ejecutivo. La corte suprema de siete magistrados tuvo carácter de vitalicia, prestándole mucha autoridad y estabilidad, pero fue empacada de conservadores, dando una señal de que el sesgo del sistema judicial no iba a modificarse en mucho tiempo. El propio gobierno no estaba sujeto a su constitución y no había corte alguna que pudiera tratar el tema de la vulneración de la ley y de la constitución por el gobierno.

Un elemento importante de la constitución que continuó con una tradición liberal fue la defensa del principio de propiedad privada. Existe protección de los contratos privados (artículo 31), pero el interés privado debía someterse en caso de conflicto al interés público, donde «las expropiaciones que sea preciso hacer requieren plena indemnización». Sin embargo, el Banco Nacional al emitir en exceso vulneró los contratos que hacían los agentes entre sí y el Estado, al restarle valor de manera arbitraria a los activos que se intercambiaban y en especial a los ahorros del público, algo que a Caro lo tenía sin cuidado, como lo revela la siguiente afirmación suya: «La sobre valuación de la moneda es prerrogativa del soberano, sólo que pugna con preocupaciones arraigadas», como las de perder los ahorros o ver reducidos los salarios reales de los empleados.

En balance, las políticas monetarias y financieras de la Regeneración frenaron el surgimiento de una burguesía y de un sistema financiero que apalancara el desarrollo económico. "La emisión de papel es un recurso especialísimo, gratuito», repetía Caro, sin querer percatarse de que la inflación constituía un pesado impuesto para la sociedad y que cuando superara los dos dígitos, como ocurrió durante la guerra de los mil días, destruiría los fundamentos del intercambio y del propio desarrollo capitalista.

En términos muy generales, el desarrollo económico surge de varios requisitos: un sistema político que garantice escenarios de negociación pacífica de intereses, instituciones que permitan y fomenten el ahorro y la inversión, derechos de propiedad sino justos por lo menos legítimos, exis- 
tencia de justicia independiente, educación universal que permita la absorción de la ciencia y la técnica y, no menos, moneda sana. Todas estas condiciones fueron vulneradas por los gobiernos de la Regeneración que se basaban en conceptos religiosos dogmáticos que pretendían exterminar el liberalismo de la faz del país, que organizaron escenarios políticos de los cuales quedaron excluidos hasta los hombres ricos de la época, y que recurrieron a la represión y al destierro de sus enemigos, depredaron la moneda y frenaron el desarrollo intelectual y científico de las universidades. Las evidencias empíricas informan que el crédito se paralizó durante los últimos quince años del siglo XIX, que muchos bancos se liquidaron y que la creciente inflación fue un freno del crecimiento económico (Ocampo, 1993).

Núñez entendió bien que el país necesitaba seguridad y orden. «Por lo general, "el liberalismo nunca pudo consolidar las bases de su propia estabilidad", mientras que los conservadores se convirtieron en los grandes "proveedores" de estabilidad política y atrajeron a políticos liberales claves que se aliaron con ellos» [Gargarella (2005), 247]. La centralización emprendida por Núñez dio pie a un ejército nacional fuerte que limitó la sedición regional y nacional, prestándole mayor legitimidad al Estado. Otra tarea fundamental exigida por el desarrollo de largo plazo del país fue establecer un mercado interno sin aduanas interiores, que se obtuvo aboliendo la soberanía de los otrora nueve grandes Estados.

La República tuvo también una regla de sucesión clara pero sesgada del partido en el poder, con serios problemas en los derechos de la oposición (vetos a la participación liberal en el congreso) y de manipulación electoral. La regla electoral mayoritaria, "ganador toma todo", que reemplazó la que primó durante la fase federal —el perdedor a nivel nacional podía ganar las elecciones en uno o más estados soberanos- y la introducción de elecciones indirectas, se prestó a un aumento del fraude en determinar los resultados electorales. Por ejemplo, «entre 1896 y 1904, los liberales pudieron elegir solamente dos miembros de la Cámara de Representantes y a pesar de que su partido disfrutaba sólo de un apoyo minoritario a escala nacional, hubieran podido ganar en muchos distritos electorales si la elección se hubiera llevado a cabo de manera justa» [Bushnell (1994), 204]. Había una combinación letal entre revolución y fraude, porque los que ganaban la guerra hacían fraude similar al que, según ellos mismos, les había imposibilitado acceder al poder por las vías electorales. La oposición liberal se convenció entonces que su única opción de poder era la guerra.

En los temas sociales, la Regeneración adoptó la visión cristiana de que la pobreza se podía enfrentar con la caridad: la salud y la educación públicas debían ser atendidas por la Iglesia con limosnas y unas escasas transferencias del gobierno central, lo cual hizo que las coberturas fueran muy pequeñas. Caro consideraba incluso que la pobreza era necesaria para 
poder expresar la virtud de la caridad. La educación primaria se declaró como gratuita pero no obligatoria, contra la visión liberal de universalizarla, mientras su contenido debía estar acorde con la fe religiosa y su pedagogía se basaba en la memoria y la represión. El tema de la patria potestad en cabeza de las familias de los párvulos fue defendida por los conservadores, en una situación en la cual la mayoría de los niños trabajaban en vez de ir a la escuela, mientras que los liberales la ponían en control del Estado en el tema de la educación que debía eventualmente ejercer una cobertura universal, algo que a duras penas se ha alcanzado para la escuela primaria ya en el siglo XXI.

Se gestó así un Estado pequeño que no tenía por qué inmiscuirse en los temas sociales ni cobrar impuestos para financiar la educación y menos la salud. La carencia de bienes públicos sería un lastre para un desarrollo económico más profundo durante el siglo Xx. El arancel durante la Regeneración no fue especialmente alto, pues fue socavado por la creciente inflación que generaba el régimen de moneda del curso forzoso.

Aún si el país requería centralismo, sus excesos le restaron legitimidad a la tributación, en la medida en que alejaba al contribuyente de las decisiones de cuánto debía pagar y cómo se gastaban los fondos recaudados. Los encargados de gastar no tenían controles para impedir que hicieran tratos corruptos, dada la ausencia de poderes alternos, de contraloría y de superintendencias que vigilaran las cuentas del gobierno. Los aranceles y el impuesto inflacionario sumieron al ciudadano en la más profunda inconsciencia sobre quién pagaba por el Estado, que no era precisamente el que más podía hacerlo. El Estado aparece así como padre milagroso, transfigurado por la religión, capaz de resolver todos los problemas por rogativas y favores, no como resultado terrenal de los impuestos contribuidos por los ciudadanos que tenían derecho a disfrutar de bienes públicos.

Caro pretendió imponerle impuestos a las exportaciones de café en 1894, algo que unificó a los terratenientes de Cúcuta, Cundinamarca y Tolima con los cafeteros medianos, comerciantes y banqueros de Antioquia en su contra. También se unieron a la búsqueda del orden y del progreso los terratenientes del Valle del Cauca, liderados por el empresario norteamericano James Eder, que esperaban prosperar con su difícil conexión al mercado mundial por Buenaventura [Mina (1975), 75]. «Sólo con el crecimiento de la demanda externa, mejoras en el transporte y oportunidades económicas crecientes surgió una clase terrateniente (y comercial) con la riqueza y la visión requerida para apoyar un gobierno eficiente o por lo menos alguna clase de orden incluyente» [Safford (1992), 92].

Éste fue el principio del fin de la Regeneración que sería remplazada después de la guerra civil por una alianza regional y política que introduciría una nueva regla electoral, el voto incompleto, que permitiría la representación del perdedor con un tercio de las posiciones elegidas y en el gabi- 
nete del gobierno central. Las reformas de 1910 limarían los aspectos más corrosivos de la Constitución de 1886, como el debilitamiento del ejecutivo que bajó de seis a cuatro años su período, un fortalecimiento relativo del legislativo y una justicia que había sido fortalecida en la constitución de 1886, tornándola en una carta de navegación aceptable para la paz política y conducente al crecimiento económico moderno que alcanzó Colombia en el siglo xx (Mazzuca, Robinson, 2007).

\section{LAS TENDENCIAS ECONÓMICAS DE LARGO PLAZO}

¿Cuál fue el efecto económico de los cambios constitucionales y legales a que fue sometida la sociedad colombiana durante el siglo XIX? ¿Cuál fue la verdadera herencia colonial en tercios de crecimiento económico? ¿Qué se podría esperar de una economía que sufrió nueve cambios de reglas de juego generales durante el siglo?

La economía colombiana durante el siglo XIX tuvo un comportamiento muy pobre, especialmente si se le compara con el notable crecimiento que obtuvo durante la segunda mitad del siglo XVIII, donde la minería del oro actuó como sector líder. Se trató de un crecimiento pre-industrial, incentivado por la rebaja de impuestos que otorgó el gobierno borbónico a la minería ${ }^{14}$. y por la estabilidad política que perduró por más de trescientos años [Kalmanovitz (2006), 163].

GRÁFICO 1

GASTO GOBIERNO CENTRAL EN EL PIB

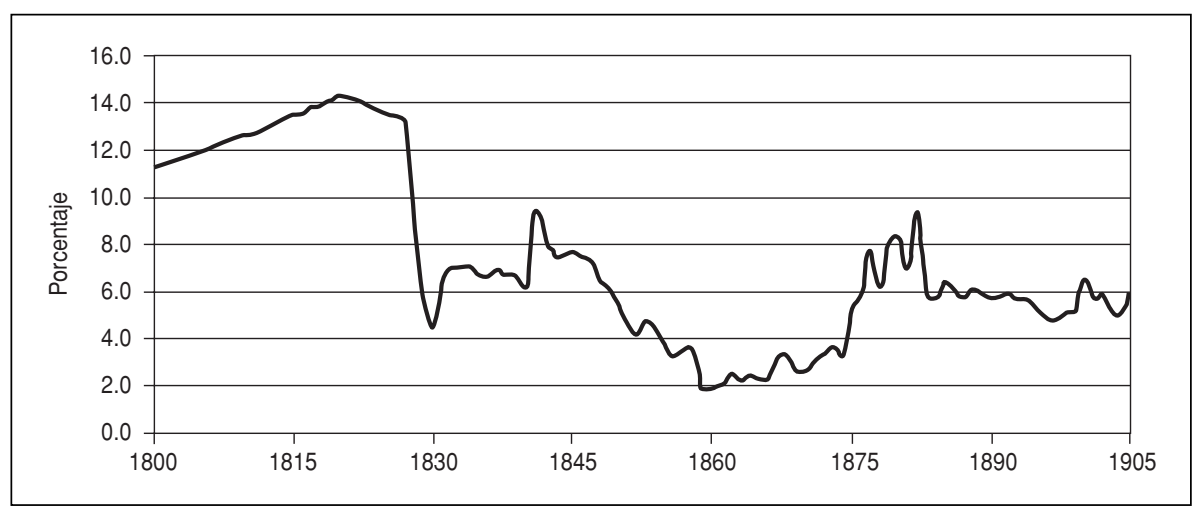

Fuente: Junguito (2007) y cálculos propios.

${ }^{14}$ Los borbones incentivaron el auge minero con la reducción de los impuestos a la producción de oro, que pasó de cerca el 22 por cien del oro extraído, que sumaban el quinto y el requinto, a un 3 por cien aproximadamente. 
La ineficiencia de la organización económica colonial no hacía imposible el crecimiento económico, asociado a la producción y exportación de oro. Contra la visión de los criollos y de la historiografía tradicional de que la opresión colonial impedía todo progreso económico, el virreinato de la Nueva Granada mantuvo un sector minero dinámico, que creció al 2,5 por cien anual entre 1750 y 1800 , tasa notable para una economía precapitalista y que jalonó otros sectores de la economía colonial. Un cálculo aproximado del crecimiento del producto colonial entre 1750 y 1800 sería de 1,2 por cien anual, 0,3 por cien correspondiente a la productividad surgida de una mayor división y especialización del trabajo de las diferentes regiones geográficas del virreinato y 0,9 por cien anual al crecimiento demográfico, correspondiente al período ínter censal de 1778 y 1825 [Kalmanovitz (2006), 176].

Es claro también que los federalistas logran construir estado a nivel regional, claro que con el consecuente debilitamiento del gobierno central, como lo muestra el gráfico siguiente. Siempre el tamaño del Estado durante el siglo XIX dependió casi totalmente del comercio exterior alcanzado por el país.

GRÁFICO 2

RUTAS NACIONALES Y REGIONALES

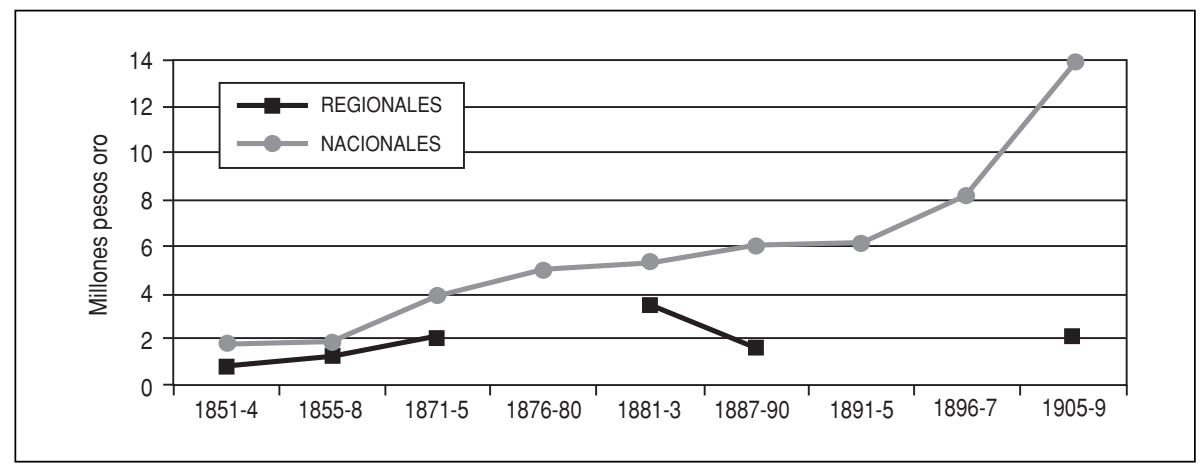

Fuente: Ocampo, 1984B.

El comercio exterior se desarrolló poco durante los gobiernos de La Regeneración, comparado con el período $1850-1880$ y los primeros treinta años del siglo Xx. Contrasta con el marcado ascenso que vivió el comercio bajo los incentivos de los liberales, a pesar del descalabro tabacalero. Incluso con respecto al café, sus exportaciones físicas despegan seriamente sólo en el siglo XX, liquidada la guerra y modificadas las reglas de juego político para hacerlas menos oprobiosas (gráfico 3). 
GRÁFICO 3

EXPORTACIONES FÍSICAS CAFÉ

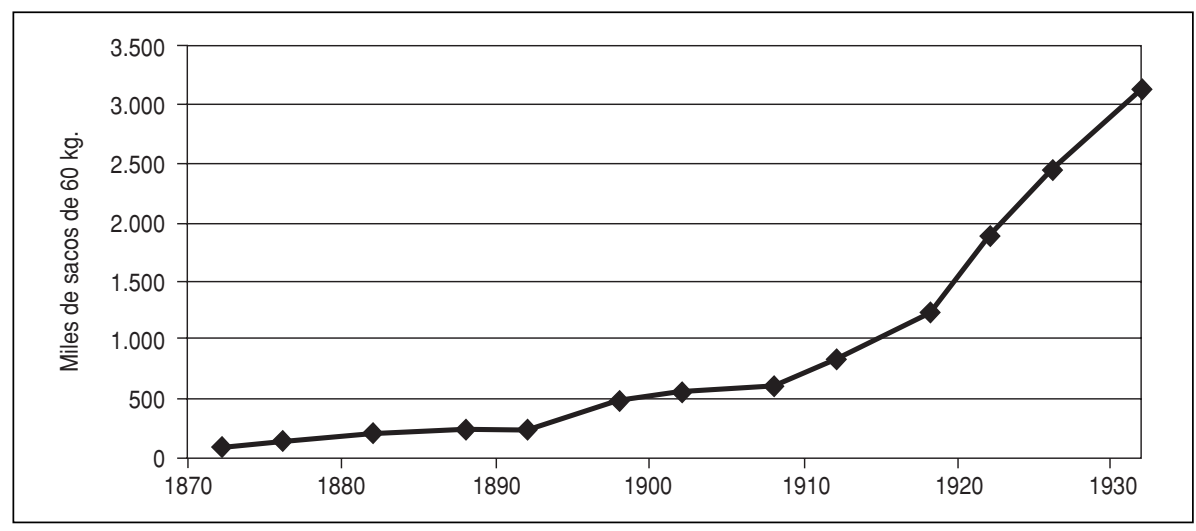

Fuente: Ocampo, 1984A.

GRÁFICO 4

PIB POR HABITANTE 1765-1905

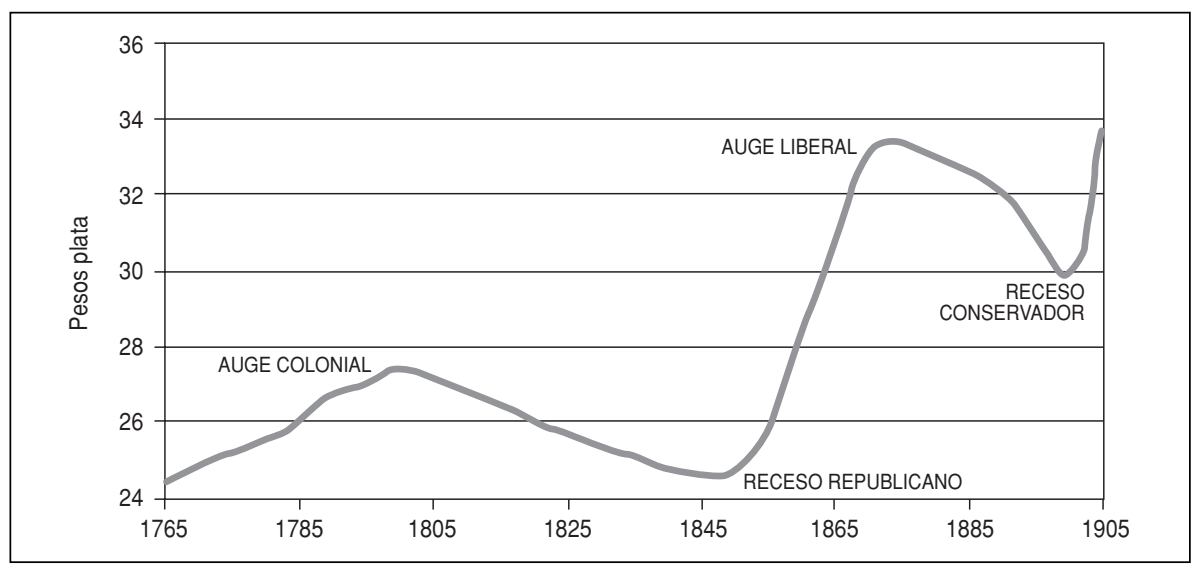

Fuente: Kalmanovitz, 2006B; Kalmanovitz, López Rivera, 2007.

Las fases de crecimiento se expresan más claramente en el cuadro 2.

Para todo el siglo XIX, de acuerdo con nuestro cálculo, el PIB por habitante creció sólo al 0,1 por cien anual y la población al 1,7 por cien (Flórez, Romero, 2007). El crecimiento económico fue mayor a partir de 1833 y se aceleró entre 1851 y 1886, cuando alcanzó 0,5 por cien anual. Es de destacar que las políticas liberales, sobre todo frente a la abolición del estanco 
CUADRO 2

CRECIMIENTO DEL PIB POR HABITANTE Y DE LA POBLACIÓN

\begin{tabular}{|c|c|c|c|}
\hline & PIB (\%) & PIB per capita (\%) & Población (\%) \\
\hline $1800-1905$ & 1,7 & 0,1 & 1,7 \\
$1800-1832$ & 1,3 & $-0,2$ & 1,6 \\
$1833-1850$ & 1,8 & 0,2 & 1,6 \\
$1851-1886$ & 2,2 & 0,5 & 1,7 \\
$1887-1905$ & 1,2 & $-0,5$ & 1,8 \\
\hline
\end{tabular}

Fuente: Kalmanovitz, López Rivera, 2007; Flórez, Romero, 2007.

del tabaco y de las restricciones al comercio del oro de 1846 [Botero (2007), 59], hicieron una fuerte diferencia en el crecimiento del PIB frente a la trayectoria anterior de la economía. Entre 1887 y 1905 hay una contracción producida por circunstancias internacionales, el conflicto interno y por las políticas de La Regeneración que condujo a que en los últimos quince años del siglo el PIB por habitante se contrajera calamitosamente al $-0,5$ por cien anual.

El comportamiento económico colombiano fue similar al de otras economías colonizadas por España con fuerte arraigo de sus instituciones políticas, legales y económicas, como México y Perú. Esta imbricación de instituciones arcaicas puede explicar, pero solamente en parte, la dificultad para llevar a cabo las reformas liberales y los ajustes de política necesarios para aprovechar la primera gran globalización que se abre en pleno desde 1860. La lucha para modernizar el país va a generar una gran inestabilidad constitucional, una de las mayores del continente, como se demostró atrás. México despega antes que Colombia con la larga dictadura de Porfirio Díaz ${ }^{15}$, durante la cual se impone un orden despótico perdurable, se construyen ferrocarriles y se abre la economía a la inversión extranjera y al comercio internacional; a principios del siglo xx, México duplica el PIB por habitante colombiano cuando en 1850 estaban bastante próximos.

Los países más nuevos y situados en la frontera del imperio español, como Argentina y Chile, tuvieron menos problemas para establecer regímenes liberales que los condujeron a un rápido desarrollo exportador durante la segunda mitad del siglo XIX. En sentido contrario podía pensarse con Glaeser et al., que la prosperidad en la que entraron de 1850 en adelante les debió prestar estabilidad política y constitucional que se deterioró cuando el auge feneció, después de 1914. Para el caso colombiano, los obstáculos legales a la profundización de los mercados, la inestabilidad política, la fal-

15 En Colombia, el general Rafael Reyes que gobernó entre 1905 y 1909 emuló las medidas económicas del porfirato mexicano [Deas (1993), 105]. 
sificación del patrón monetario y las políticas abusivas contra la acumulación de capital de los tres últimos lustros del siglo XIX explican parte del magro resultado colombiano.

\section{CONCLUSIONES}

La herencia hispánica tuvo un fuerte peso en el desarrollo constitucional y legal del país al proveer un sistema de creencias compartidas que orientó el diseño de las reglas de juego con que se fue organizando tortuosamente la República. El derecho a la rebelión sustentado en la filosofía medieval pudo ser doblegado por la Corona que imponía un orden político que hacía respetar, pero la endémica debilidad del Estado republicano nunca pudo ponerle límites estrictos a la revuelta. La inestabilidad política que resultó de las divisiones entre las elites criollas explica más que el mismo legado hispánico el atraso económico del siglo XIX. La política pasó de los extremos democráticos de los liberales federalistas a los muy represivos que enarbolaron los conservadores cuando lograron asentarse en el poder.

Con todo, los criollos buscaron afanosamente un nuevo orden político por medio de la prueba y del error que fue posible dentro de la centralización que propiciaron las guerras por la independencia. De allí en adelante, las reformas fiscales y legales buscaron promover un desarrollo económico basado en el comercio internacional que se fue asentando también de manera pendular. Las reformas a los códigos de comercio y los que permitieron la constitución de sociedades anónimas, en comandita y limitadas, así como también de los bancos, aunque lejos de las realidades sociales que buscaban encausar, tampoco se constituyeron en impedimentos importantes a su surgimiento y algo debieron ayudar al desarrollo económico de largo plazo. Y así fueron emergiendo penosamente empresas y bancos que serían el germen del capitalismo que se desarrollaría con buena fuerza ya en el siglo XX.

La inestabilidad política y jurídica introducida por el proceso federalista, seguida por la centralización a la fuerza que implantó la Regeneración, debió ser un freno importante para la inversión y para la iniciativa de los hombres de empresa, quienes acusaron cansancio al contemplar cómo se desplomaban frecuentemente sus proyectos productivos, la construcción de obras de infra-estructura o el sistema financiero mismo, indispensables todos para el éxito de sus negocios. Los conflictos electorales y las guerras civiles debieron producir adicionalmente pérdidas físicas y resentir la escasa demanda agregada de un sistema económico muy precario que requería reglas de juego estables y de la paz política para consolidarse. Serían ellas las que garantizarían la construcción de los medios de transporte y la entrada de lleno a un proceso de crecimiento moderno, o sea continuo en el tiempo que se pudo desatar después de superada la guerra de los mil días. 
Malcom Deas en un ensayo reciente (Deas, 2007) aduce que las guerras civiles del siglo XIX, con excepción de la de los mil días, no afectaron de manera generalizada los derechos de propiedad y que, por tanto, no puede afirmarse, como lo hacen Summerhill, North y Weinsgat, que la falta de ese principio sea un factor explicativo del poco progreso del país durante este período. Sin embargo, como creemos haberlo demostrado a lo largo de este ensayo, el desorden político y constitucional sí malogró las condiciones necesarias para el desarrollo económico de largo plazo de Colombia. Puede afirmarse además que las guerras intestinas y el ocasional irrespeto a los derechos de propiedad tampoco ayudaron al crecimiento económico de largo plazo.

La Regeneración constituyó, a pesar de sí misma, una modernización del Estado al devolverle la fuerza que le habían restado los liberales, permitiéndole más adelante ejercer el papel de árbitro sobre los intereses de clase y sociales, adquirir el carácter de promotor del desarrollo económico y, muy importante también, reunificar el mercado interior. Los costos en crecimiento que la Regeneración impuso a la sociedad debieron ser sustanciales, al limitar la cobertura educativa de la población, dejar un legado cultural dogmático, contraproducente para el posterior desarrollo universitario y científico del país, y no acopiar los recursos para construir una moderna infra-estructura física. La cruenta guerra de los mil días, sin embargo, dejó una enseñanza que las capas dirigentes del país pudieron poner en práctica, apoyados en nuevas reglas de juego electorales y políticas, que en esencia respetaron a la oposición, y que sirvieron de hoja de ruta para el desarrollo económico del siglo Xx.

\section{BIBLIOGRAFÍA}

Acemoglu, D.; Johnson, S., y Robinson, J. (2001): «Institutions as the Fundamental Cause of Long-Run Growth», Working Paper 10481, http://www.nber.org/papers/w10481.

Acemoglu, D.; Johnson, S., y Robinson, J. (2005): «Los orígenes coloniales del desarrollo comparativo: una investigación empírica», Revista de Economía Institucional, núm. 13. Bogotá: Universidad Externado de Colombia.

Botero, M. M. (2007): La ruta del oro: Una economía primaria exportadora Antioquia 1850-1890. Medellín: Universidad Eafit.

Brading, D. A. (2003): «La monarquía católica», en A. Annino, F-X. Guerra (coords.), Inventando la nación. Ibero América. Siglo XIX. México: Fondo de Cultura Económica.

Burns, J. H. (ed.) (1991): The Cambridge History of Political Thought 1450-1700, Cambridge: Cambridge University Press.

Bushnell, D. (1985): El régimen de Santander en la Gran Colombia, Bogotá: Tercer Mundo Editores.

- (1994): Colombia, una nación a pesar de sí misma. Bogotá: Editorial Planeta.

CoAtsworth, J. H. (1993): «El impacto económico de la Independencia en la América Latina», en L. Prados y S. Amaral (eds.): La independencia de América Latina: Consecuencias económicas, Madrid: Alianza Editorial. 
COATSWORTH, J., y TORTELla, G. (2007): «Instituciones y desempeño económico a largo plazo en México y España (1800-2000)», en R. Dobado, R. Gómez Galvarriato y G. Márquez (comps.), México y España ¿historias económicas paralelas? México: Fondo de Cultura Económica.

CutTer, C. (1999): "The Legal Culture of Spanish America on the Eve of Independence», en E. Zimmerman (ed.), Judicial Institutions in Nineteenth-Century Latin America. Londres: Institute of Latin American Studies, University of London.

DEAS, M. (1993): Del poder y la gramática. Bogotá: Tercer Mundo Editores.

- (2007): «Inseguridad y desarrollo económico en Colombia en el primer siglo de vida republicana independiente: consideraciones preliminares». Seminario de Historia Económica de Colombia del siglo XIX, Bogotá: Banco de la República.

DYe, A. (2006): "The Institutional Framework», en V. Bulmer-Thomas, J. H. Coatsworth, y R. Cortés Conde (eds.), Cambridge Economic History of Latin America. Cambridge: Cambridge University Press.

Elliot, J. (2007): Empires of the Atlantic World, Britain and Spain in America 14921830. New Haven: Yale University Press.

ENGERMAN, S., y SOKOLOFF, K. (1999): «Dotaciones de factores, instituciones y vías de crecimiento diferentes entre las economías del Nuevo Mundo», en S. Haber (ed.), Cómo se rezagó la América Latina. México: Fondo de Cultura Económica.

- (2003): «Inequality Before and Under the Law: Paths of Long-Run Development in the Americas». Rochester: Rochester University.

FlóRez, C. E., y Romero, O. L (2007): «La demografía de Colombia en el siglo XIX», Seminario de Historia Económica de Colombia del Siglo XIX, Bogotá: Banco de la República.

García-Villegas, M. (2007): «Tradición pactista y ley de justicia y paz», Pensamiento Jurídico, núm. 19. Bogotá: Universidad Nacional de Colombia.

GARGARELLA, R. (2005): Los fundamentos legales de la desigualdad, el constitucionalismo en América (1776-1860). Madrid: Siglo XXI de España Editores.

GutiérRez, F. (1985): Curso y discurso del movimiento plebeyo 1849/1854. Bogotá: Instituto de Estudios Políticos y Relaciones Internacionales, El Áncora Editores.

Jaramillo Uribe, J.; Meisel, A., y URrutia, M. (1997): "Continuities and Discontinuities in the Fiscal and Monetary Institutions of New Granada, 1783-18cincuenta». Borradores de Economía, núm. 74. Bogotá: Banco de la República.

Junguito, R. (2007): "Finanzas públicas siglo XIX», Seminario de Historia Económica de Colombia del Siglo XIX. Bogotá: Banco de la República.

Kalmanovitz, S. (2002): "Miguel Antonio Caro, el Banco Nacional y el Estado», en R. Sierra (ed.), Miguel Antonio Caro y la cultura de su época. Bogotá: Universidad Nacional de Colombia.

- (2006): «La idea federal en Colombia durante el siglo XIX», en R. Sierra (ed.), El radicalismo colombiano del siglo XIX. Bogotá: Universidad Nacional de Colombia.

Kalmanovitz, S., y LóPEZ RIVERA, E. (2007): «El PIB colombiano durante el siglo XIX». Montevideo: Primer Congreso de Historia Latinoamericana.

LOVEMAN, B. (2003): «El constitucionalismo andino: 1808-1880», en J. Maiguashca (ed.), Historia de América andina, Creación de las repúblicas y formación de la Nación, vol. 5. Quito: Universidad Andina Simón Bolívar.

LYNCH, J. (1976): Las revoluciones hispanoamericanas 1808-1828. Barcelona: Seix Barral.

- (2001): América latina, entre colonia y nación. Barcelona: Crítica.

MARTíneZ GARNICA, A. (2006): "La recepción de la Declaración de los derechos del hombre y del ciudadano en el Nuevo Reino de Granada», en La agenda liberal tem- 
prana en la Nueva Granada (1800-1850). Bucaramanga: Universidad Industrial de Santander.

MazzucA, S., y Robinson, J. (2007): «Political Conflict and Power-Sharing in the Origins of Modern Colombia», Working Paper 12099. http://www.nber.org/papers/ w12099.

McGuire, R. A., y OHSFEldt, R. L. (1986): "An Economic Model of Voting Behavior over Specific Issues of the Constitutional Convnetion of 1787», Journal of Economic History, vol. XLVI, núm. 1 (March), pp. 79-111.

Meisel, A. (2005): “¿Situado o contrabando? La base económica de Cartagena de Indias y el Caribe colombiano en el siglo de las luces», en H. Calvo, A. Meisel (eds.), Cartagena de Indias en el siglo XVIII. Cartagena: Banco de la República.

Mina, M. (1975): Esclavitud y libertad en el Valle del Río Cauca. Bogotá: Publicaciones La Rosca.

NoRTH, D. (1993): Instituciones, cambio institucional y desempeño económico. México: Fondo de Cultura Económica.

OcAmpo, J. A. (1984A): Colombia y la economía mundial: 1830-1910, Bogotá: Siglo Veintiuno Editores.

- (1984B): "Librecambio y protección en el siglo XIX», J. A. Ocampo, en. S. Montenegro, Crisis mundial, protección e industrialización. Bogotá: Cerec, hay reedición por Editorial Norma, 2007.

- (1993): «Comerciantes, artesanos y política económica en Colombia, 1830-1880», Boletín Cultural y Bibliográfico, Bogotá: Banco de la República.

Ots y Capdequí, J. M. (1967): Historia del derecho español en América y del derecho indiano. Bogotá: Biblioteca Jurídica Aguilar.

- (1958): Las instituciones del Nuevo Reino de Granada al tiempo de la Independencia. Madrid: Consejo Superior de Investigaciones Científicas.

Phelan, J. (1980): El pueblo y el rey, Bogotá: El Áncora Editor.

Posada Carbó, E. (1992): "Más Caro, el mismo Caro», Boletín Cultural y Bibliográfico, núm. 30, vol. XXIX, Bogotá: Banco de la República.

- (1994): «Rafael Núñez: sus últimos días, Centenario de la muerte del Regenerador». Bogotá: Revista Credencial Historia, núm. 57.

- (1996): "Civilizar las urnas: conflicto y control en elecciones colombianas, 18301930». Bogotá: Boletín Cultural y Bibliográfico, núm. 39, vol. XXXII.

- (2003): «El estado republicano y el proceso de incorporación: las elecciones en el mundo andino 1830-1880», en J. Maiguashca (ed.), op. cit.

RAmírez, M. T., y SALAZAR, I. (2007): «Surgimiento de la educación en la República de Colombia, ¿En que fallamos? Seminario de historia económica del siglo XIX, Bogotá: Banco de la República.

Rodríguez, J. (1996): La independencia de América Latina. México: Fondo de Cultura Económica.

RoJAS, A. (2004): "Impactos monetarios e institucionales de la deuda pública en Colombia 1840-1890», Borradores del CIE, núm. 8, Medellín: Universidad de Antioquia.

SAFFORD, F. (1992): «Political Order in Post-Independence Spanish America», Journal of Latin American Studies, vol. 24. Cambridge: Cambridge University Press.

SAMPER, J. M. (1982): Derecho público interno. Bogotá: Editorial Temis.

SoKoloff, K., y ZoLT, E. M. (2007): «Inequality and the Evolution of Institutions of Taxation: Evidence from the Economic History of the Americas», en S. Edwards, G. Esquivel y G. Márquez (eds.), The Decline of Latin American Economies: Growth, Institutions, and Crises. Chicago: The Chicago University Press. 
SUÁREZ, F. (1956): Guerra, intervención, paz internacional, estudio, traducción y notas de Pereña Vicente, L. Madrid: Editorial Espasa Calpe.

Summerhill, W.; NorTh, D., y WeINGAST, B. (2005): «Orden, desorden y cambio económico: Latinoamérica vs. Norte América», Revista Instituciones y Desarrollo núm. 12-13. Barcelona: IIG.

Uribe-Urán, V. (2000): Honorable Lives. Lawyers, Family, and Politics in Colombia, 1780-1850. Pittsburgh: University of Pittsburg Press.

Urrutia, M., y ARrubla, M. (1970): Compendio de estadísticas históricas de Colombia. Bogotá: Universidad Nacional de Colombia.

Urueña Cervera, J. (2007): Nariño, Torres y la Revolución Francesa. Bogotá: Ediciones Aurora.

- (2004): Bolívar republicano, Bogotá: Ediciones Aurora.

WeIngast, B. (1995): «The Economic Role of Political Institutions: Market Preserving Federalism and Economic Growth», Journal of Law, Economics and Organization, núm. 11. Oxford: Oxford University Press 
